\author{
Федеральное государственное бюджетное учреждение \\ «27 Научный чентр» Министерства обороны Российской Федерации, 105005, \\ Российская Федерация, г. Москва, Бригадирский пер., д. 13
}

Поступила 15.05.2021 г. Принята к публикации 20.06.2021 г.

Несмотря на внимание к проблемам военных преступлений и преступлений против человечности, которые в беспрецедентных масштабах совершались в нацистских концентрационных лагерях, тема медицинских экспериментов на заключенных в современной отечественной историографии представляется одной из наименее изученных. Тем более не уделялось специального внимания испытаниям на людях химического оружия. Цель работы - рассмотреть историю разработки и испытаний на людях боевых отравляющих веществ (БОВ) в Германии в 1933-1945 гг. В годы Первой мировой войны Германия была одной из ведущих стран мира в области военно-химического дела. В результате версальских ограничений этот потенциал был в значительной степени утрачен. После прихода к власти Национал-социалистической немецкой рабочей партии (НСДАП) Германия не только восстановила, но и нарастила военную мощь, достигнув в области химического оружия над своими противниками качественного превосходства. Испытания БОВ, а также исследование эффективности средств и протоколов лечения вызванных ими поражений, проводили как военные структуры Вермахта и СС, так и гражданские научно-исследовательские и академические институты. Эксперименты на заключенных осуществлялись в концентрационных лагерях Дахау, Равенсбрюк, Аушвиц-Биркенау, Бухенвальд, Заксенхаузен, Нацвайлер-Штрутгоф, Нойенгамме и др. В основном исследовалось поражающее действие сернистого иприта и фосгена. В Аушвице-Биркенау «производилось изучение действия разных химических препаратов по заказам немецких фирм». Врачи из СС, ставившие недобровольные опыты на людях, после войны были осуждены военными трибуналами за военные преступления и преступления против человечности. Семь врачей были приговорены к смертной казни через повешение, приговор приведен в исполнение 2 июня 1948 г. в тюрьме для военных преступников в Ландсберге (Бавария). По итогам процесса 1947 г. был составлен Нюрнбергский кодекс - первый международный документ, вводивший этические нормы для ученых, занимающихся экспериментами на людях. Он включал в себя 10 принципов, главный из которых сводился к тому, что для проведения эксперимента на человеке необходимо его добровольное осознанное согласие после предоставления ему полной информации о характере, продолжительности и цели проводимого эксперимента; о методах и способах его проведения; обо всех предполагаемых неудобствах и опасностях, связанных с проведением эксперимента, и, наконец, возможных последствиях для физического или психического здоровья испытуемого, могущих возникнуть в результате его участия в эксперименте.

Ключевые слова: боевые отравляющие вещества; военные преступления; Вторая мировая война; Германия; испытания; конилагерь; Нюрнбергский трибунал; преступления против человечности.

Библиографическое описание: Шило Н.И. Разработка и испытания на людях боевых отравляющих веществ и средств лечения поражений в Германии в 1933-1945 годах// Вестник войск РХБ защитыы. 2021. Т. 5. № 2. C. 173-198. https://doi.org/10.35825/2587-5728-2021-5-2-173-198 
В годы Первой мировой войны (1914-1918) Германия была одной из ведущих стран мира в области военно-химического дела $[1,2]$. Главным центром военно-химических исследований был Институт физической химии и электрохимии кайзера Вильгельма (нем. - Kaiser Wilhelm Institut für physikalische Chemie und Elektrochemie, KWIPC) (ИФХЭ) Общества кайзера Вильгельма (нем. - Kaiser Wilhelm Gesellschaft) ${ }^{1}$ (Берлин-Далем) (рисунок 1) [3, 4].

В институте занимались поиском токсичных химикатов, пригодных к применению в качестве боевых отравляющих веществ, разработкой технологий их производства в промышленных масштабах, созданием средств доставки, вопросами хранения и утилизации, разработкой средств и способов обнаружения боевых отравляющих веществ (БОВ), а также средств индивидуальной и коллективной защиты. Там же занимались изучением токсикологических свойств БОВ и поиском средств и методов лечения поражений. Директор ИФХЭ Фриц Габер (нем. Fritz Haber, 1868-1934) (Нобелевский лауреат, 1918) был одновременно начальником военно-химической службы германской армии.

Крупнейшим токсикологическим центром, занимавшимся БОВ, был Департамент Е (фармакологический) ИФХЭ под руководством токсиколога Фердинанда Флури (нем. - Ferdinand Flury, 1877-1947).

После окончания Первой мировой войны, завершившейся поражением Германии и ее союзников, Версальский мирный договор (1919) специально оговаривал (ст. 171): «B виду воспрещения пользования удушливыми, ядовитыми или тому подобными газами, а также всякими аналогичными жидкостями, веществами или способами, производство и ввоз их в Германию строго воспреща ется. То же самое будет относиться к материалу, специально предназначенному для изготовления, сохранения или применения названных продуктов и способов...». Запрещались производство и импорт прекурсоров. Нельзя было проводить никаких секретных работ в области военной химии. В ИФХЭ департамент Е был закрыт. Германию обязали поделиться технологиями с бывшими противниками - ст. 172 Версальского мирного договора предполагала, что «в трехмесячный срок со дня вступления в силу настоящего Договора Германское Правительство доведет до сведения Правительств Главных Союзных и Объединившихся Держав о видах и способах производства всех взрывчатых веществ, ядовитых составов или других химических препаратов, употребляв-

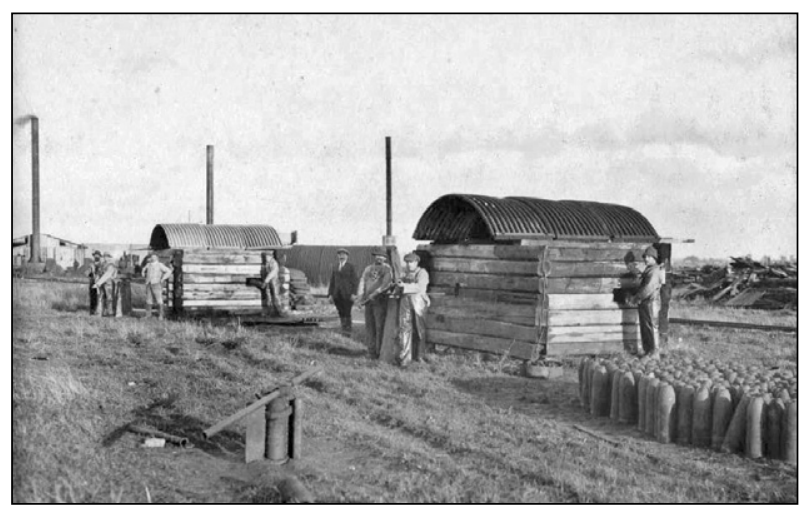

Рисунок 1 - Объект УХО образца начала ХХ века. Верден, 1919 г. Расснаряжение проводилось в деревянных бараках (в чентре). На переднем плане расснаряженные боеприпасы со снятыми взрывателями. На заднем плане - печи для сжигания uприта. Источник - GEKA [28]

шихся им в течение войны или изготовленных им с иелью употребить их таким образом» [5].

Вскоре в Германии нашли способы обхода версальских ограничений. Внутри страны научно-исследовательские работы (НИР), связанные с БОВ, велись в ограниченных масштабах группами ученых в лабораториях при университетах и научно-исследовательских центрах таких, как Биологический центр в Берлине (Biologische Reichsanstalt). Рейхсвер осуществлял взаимодействие с ними через систему контрактов. Часть работ была перенесена за пределы страны [6].

Если не принимать во внимание версальские ограничения, в этих работах не было ничего противозаконного с точки зрения международного права того времени, поскольку действовавший в то время Женевский «Протокол о запрещении применения на войне удушливых, ядовитых или других подобных газов и бактериологических средств» $(1925)^{2}$ запрещал только применение химического оружия. Готовиться к войне никакой закон не запрещал [7].

Ситуация изменилась после выборов 1933 г. с приходом к власти Национал-социалистической немецкой рабочей партии (НДСАП, нем. Nationalsozialistische Deutsche Arbeiterpartei, NSDAP) во главе с Адольфом Гитлером (нем. - Adolf Hitler, 1889-1945), ставшим рейхсканцлером. Вскоре Германия отказалась от военных статей Версальского договора, стала восстанавливать вооруженные силы и наращивать производство вооружений, в том числе химических. НИР по химическому оружию

\footnotetext{
В настоящее время - Общество научных исследований имени Макса Планка (нем. - Max Planck Gesellschaft zur Förderung der Wissenschaften e.V., MPG), сеть научно-исследовательских организаций, включающая в себя более 80 институтов и научно-исследовательских центров. Штаб-квартира находится в Мюнхене.

2 Протокол о запрещении применения на войне удушливых, ядовитых или других подобных газов и бактериологических средств. URL: https://docs.cntd.ru/document/901753260 (дата обращения: 12.06.2021)
} 


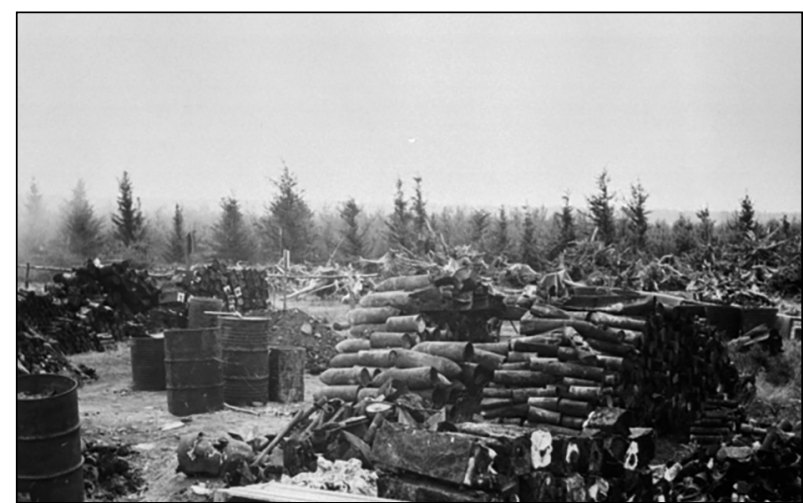

Рисунок 2 - Химические трофеи, доставшиеся союзникам после Второй мировой войны. Источник - GEKA [28]

получили дополнительное финансирование. Были созданы новые научно-исследовательские и испытательные центры, для них потребовался экспериментальный материал, война дала его в неограниченных количествах [8].

Цель работь - рассмотреть историю разработки и испытаний на людях боевых отравляющих веществ (БОВ) в Германии в 1933-1945 гг.

Основным центром научно-исследовательских и испытательных работ по химическому оружию стал учебный и испытательный полигон Вермахта и лаборатории в Раубкаммере возле Мюнстера (Heeresversuchsstelle Munster-Nord / Raubkammer) [9].

Полевые испытания, а также строительство соответствующих объектов начались в Раубкаммере в 1935 г. В 1936 г. строительство было завершено. В годы Второй мировой войны там работали около 500 человек, максимальная численность персонала достигла 800 человек (1944). Учебный полигон общей площадью $16 \times 8$ км, расположенный севернее Мюнстера, использовался как экспериментальная площадка в интересах химической службы Вермахта (в первую очередь

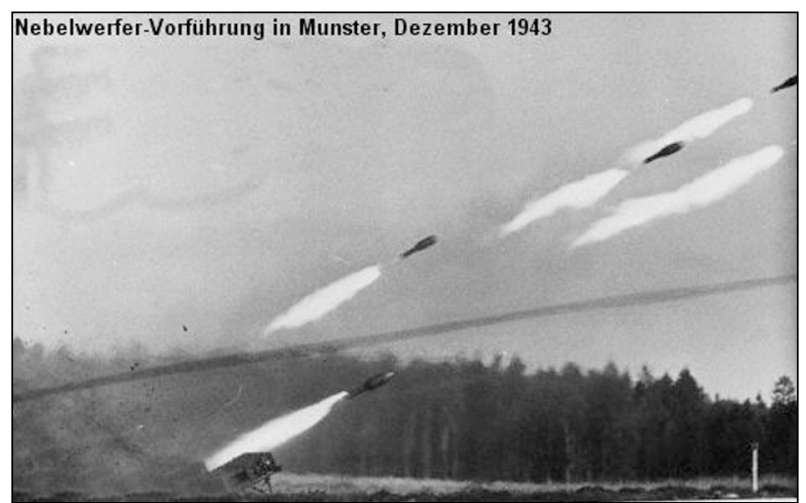

Рисунок 3 - Испытания реактивных минометов. Мюнстерский полигон. Декабрь 19432. URL: https://www.geschichtsspuren.de/artikel/ trainings-und-versuchsanlagen/108-munsterkampftstoffe.html (дата обращения: 13.06.2021)

для проведения испытаний боеприпасов с ипритом $^{3}$ (рисунок 2), а также для отработки тактических приемов ведения химической войны) и $\mathrm{BBC}$, а также как учебный полигон ${ }^{4}$ (рисунок 3). В частности, именно на испытательном полигоне в 1937 г. был построен первый пилотный объект по получению табуна, где уже к середине года наладили его маломасштабное производство 5 [10].

Вторым по величине и значимости объектом была Лаборатория противохимической защиты (Heeresgasschutzlaboratorium Spandau) в цитадели Шпандау (Берлин), созданная 9-м (химическим) отделом Управления вооружений сухопутных войск. Этот отдел осуществлял руководство и контроль над всеми НИР и испытаниями в области БОВ (боеприпасами занимался другой отдел Управления вооружений, а авиационные боеприпасы находились в ведении Люфтваффе). В цитадели Шпандау работали около 450 человек (1944). Помимо решения задач противохимической обороны, там велись работы по созданию новых БОВ, а также

\footnotetext{
В документах того времени иприт назывался Lost - сокращение от фамилий химика-технолога фирмы «Bayer» Фрица Вильгельма Ломмеля (нем. - Fritz Wilhelm Lommel, 1875-1968) и профессора Высшей технической школы в Карлсруэ (Technische Hochschule Karlsruhe) Георга Вильгельма Штайнкопфа (нем. - Georg Wilhelm Steinkopf, 1879-1949). Будучи приглашенными на работу в Институт физической химии и электрохимии Общества кайзера Вильгельма, они весной 1916 года предложили метод производства иприта в промышленных масштабах.

4 Полигон для испытаний БОВ - газовый полигон «Брелох» (Gazplatz Breloch) был организован севернее Мюнстера в 1916 г. Он функционировал почти всю войну. Однако в результате несчастного случая 24 октября 1919 г. - взрыва эшелона с химическими боеприпасами, который должен был отправляться на уничтожение (затопление в Балтийском море), почти вся инфраструктура по производству, снаряжению и хранению сотен тысяч химических боеприпасов оказалась уничтоженной (в общей сложности 42 здания), а весь район - надолго заражен. Поэтому в 1935-1938 гг. ее пришлось создавать фактически заново. Созданные в 1930-х гг. объекты, в том числе подземные снаряжательные цеха и хранилища боеприпасов, были ликвидированы в 1948 г. [11].

5 Основное производство табуна было развернуто в другом месте, с привлечением ресурсов гражданской промышленности. 7 сентября 1939 г. Совет директоров крупнейшего в стране объединения концернов химической и фармацевтической промышленности - I.G. Farbenindustrie совместно с представителями военного командования приняли решение о строительстве завода по промышленному получению табуна в Дихернфюрте-на-Одере (недалеко от Бреслау в Силезии) с проектной мощностью 1000 т/мес. Строительство началось в середине марта 1940 г. В мае 1942 г. завод был пущен в эксплуатацию.
} 
Таблица 1 - Организация научно-исследовательских работ по химическому оружию в военных структурах Германии периода Второй мировой войны [9]

\begin{tabular}{|c|c|c|c|}
\hline $\begin{array}{c}\text { Учебный и испытательный } \\
\text { полигон Вермахта } \\
\text { и лаборатории в } \\
\text { Раубқаммере (Мюнстер) }\end{array}$ & $\begin{array}{c}\text { Центр противохимической } \\
\text { защиты при 9-м отделе } \\
\text { Управления вооружений } \\
\text { сухопутных войск }\end{array}$ & \multicolumn{2}{|c|}{$\begin{array}{c}\text { Лаборатория противохимической защиты } \\
\text { (Heeresgasschutzlaboratorium), Шпандау }\end{array}$} \\
\hline & & Департамент & Научные исследования \\
\hline RI: Полигонные испытания & $\begin{array}{l}\text { 1: Организационно-плановый } \\
\text { отдел и дирекция }\end{array}$ & F1 & Химический синтез \\
\hline RII: Отдел химического анализа & 2: Отдел химической защиты & \multirow{7}{*}{$\mathrm{F} 2$} & Аналитический \\
\hline $\begin{array}{l}\text { RIII: Отдел дегазирующих } \\
\text { рецептур и средств } \\
\text { обнаружения боевых ОВ }\end{array}$ & $\begin{array}{l}\text { 3: Отдел дегазации и } \\
\text { химической защиты }\end{array}$ & & Лаборатория 1 - поляриметрия \\
\hline $\begin{array}{l}\text { RIV: Автопарк и ремонтные } \\
\text { мастерские }\end{array}$ & 4: Механический отдел & & Лаборатория 2 - зарин и табун \\
\hline $\begin{array}{c}\text { 5: Отдел вспомогательных } \\
\text { исследований }\end{array}$ & $\begin{array}{l}\text { 5: Отдел вспомогательных } \\
\text { исследований }\end{array}$ & & Лаборатория 3 - испытательная \\
\hline 6: Отдел дымовых средств & 6: Отдел дымовых средств & & Лаборатория 4 - иприт \\
\hline 7: Полигонные испытания & 7: Полигонные испытания & & Лаборатория 5 - испытания в камере \\
\hline $\begin{array}{l}\text { 8: Отдел производства боевых } \\
\text { ОВ (технологический отдел) }\end{array}$ & $\begin{array}{l}\text { 8: Производство боевых ОВ } \\
\text { (технологический отдел) }\end{array}$ & & Лаборатория 6 - исследования зарина \\
\hline 9: Финансовый отдел & 9: Финансовый отдел & \multirow{6}{*}{ F3 } & Микрохимический \\
\hline $\begin{array}{c}\text { 10: Отдел зажигательных } \\
\text { средств }\end{array}$ & $\begin{array}{c}\text { 10: Отдел зажигательных } \\
\text { средств }\end{array}$ & & Микрохимический и физико-химический \\
\hline 11: Патентный отдел & 11: Патентный отдел & & Физических измерений \\
\hline 12: Ветеринарный отдел & 12: Ветеринарный отдел & & Дымовых средств \\
\hline \multirow[t]{21}{*}{ 13: Разведывательный отдел } & 13: Разведывательный отдел & & Адсорбции и десорбции углей \\
\hline & & & Измерительный \\
\hline & & $\mathrm{F} 4$ & Измерительный \\
\hline & & F5 & Библиотека \\
\hline & & IIL & Средства индивидуальной защиты \\
\hline & & IIIL & Средства коллективной защиты \\
\hline & & IIlaL & Фильтры \\
\hline & & IIIbL & Определение боевых ОВ \\
\hline & & IIICL & Дегазация, химические боеприпасы \\
\hline & & IVL & Механический \\
\hline & & VWL & Физиологически активные вещества \\
\hline & & \multirow{5}{*}{ ViaL } & Дегазации почвы \\
\hline & & & Лаборатория 1: аэрозоль \\
\hline & & & Лаборатория 2: органической химии \\
\hline & & & Лаборатория 3: органической химии \\
\hline & & & Лаборатория 4: иприт \\
\hline & & VIbL & Дымогенераторы \\
\hline & & VicL & Разработка и испытание боеприпасов \\
\hline & & VidL & Метеорологический \\
\hline & & VIIL & $\begin{array}{c}\text { Токсикологический институт (испытания } \\
\text { на животных и на людях) }\end{array}$ \\
\hline & & VIIIL & Производство и хранение ОВ \\
\hline
\end{tabular}

по испытанию старых, главным образом кожно-нарывных. Испытывались они на лабораторных животных - кошках и мышах, реже - на собаках и обезьянах. На завершающих этапах испытаний сотрудники Лаборатории привлекали людей - добровольцев ${ }^{6}[12]$.

Кроме того, в Берлине был создан отдельный Центр противохимической защиты при

6 Испытания БОВ на людях - не чисто немецкое изобретение. В прошлом такая практика была распространена и в ряде других стран. В частности, в США к концу Второй мировой войны насчитывалось порядка 60 тыс. человек - военнослужащих, на которых испытывали БОВ, в частности, иприт и люизит [13, 14]. Об ис- 


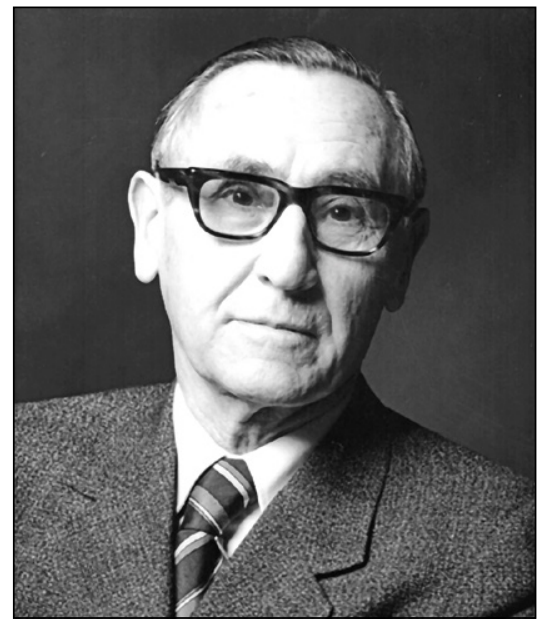

Рисунок 4 - Вольфганг Bupm (URL: https://de.wikipedia.org/ wiki/Datei:Foto_Wolfgang_Wirth_. jpg; дата обращения: 13.06.2021)

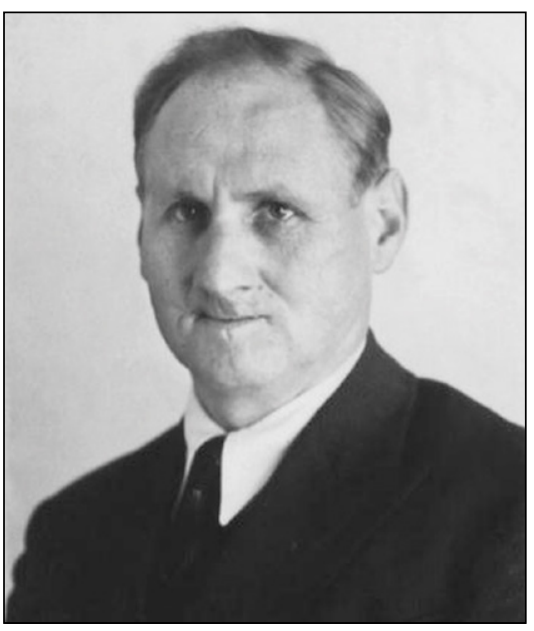

Рисунок 5 - Август Xирт (нем. - August Hirt, 1898-1945, покончил жизнь самоубийством) [19]

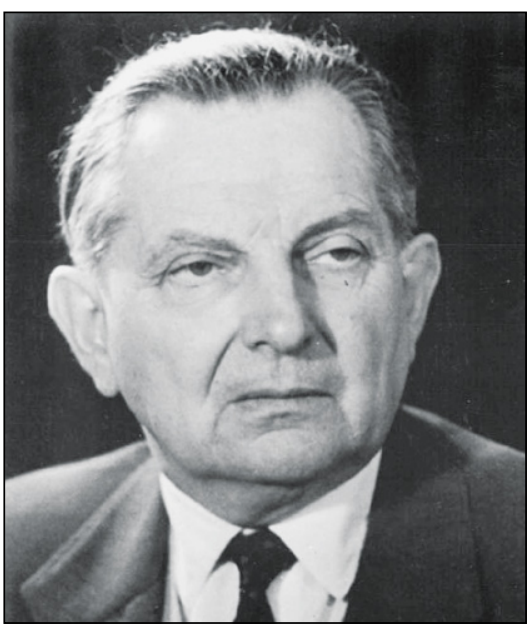

Рисунок 6 - Петер Адольф ТисceH. (URL: https://en.wikipedia.org/ wiki/Peter_Adolf_Thiessen\#/media/ File:Bundesarchiv Bild 183-832850019,_Peter_Adolf_Thiessen.jpg; дата обращения: 13.06.2021) 9-м отделе Управления вооружений сухопутных войск. Там работали 143 человека, максимум - 200 человек (1944).

Организация научно-исследовательских работ по химическому оружию в военных структурах Германии периода Второй мировой войны представлена в таблице 1.

В октябре 1934 г. в Берлине открылась Военно-медицинская академия (Militärärztliche Akademie). В интересах военно-химического дела в академии работал Институт фармакологии и военной токсикологии (Institut für Pharmakologie und Wehrtoxikologie) под руководством Вольфганга Вирта (рисунок 4)7.

Соответствующие кафедры или научно-исследовательские организации и группы усилиями Военно-медицинской академии и 9-го отдела Управления вооружений были созданы в университетах Марбурга, Мюнстера, Гессена и Вюрцбурга (Фармакологический институт при Вюрцбургском университете), а также при Медицинской академии в Данциге.

С начала 1940-х гг. к работам по химическому оружию подключилась СС. Изучением воздействия БОВ на человеческий организм занимался отдел медицинских программ Института военно-научных прикладных исследований (Institut für Wehrwissenschaftliche Zweckforschung der Waffen-SS). Этот институт был создан в июле 1942 г. организацией «Немецкое общество по изучению древней германской истории и наследия предков» (Forschungsgemeinschaft Deutsches Ahnenerbe), которая в 1937 г. вошла в состав CC (SS-Ahnenerbe) и была передана в Личный штаб рейхсфюрера СС. Отделом медицинских программ руководил антрополог, гауптштурмфюрер СС профессор Август Хирт [16, 17], с ноября 1941 по ноябрь 1944 г. возглавлявший также Анатомический институт

пытаниях на людях фосфорорганических ОВ в США и Великобритании по материалам британских архивных документов см. [15].

Вольфганг Вирт (нем. - Wolfgang Wirth, 1898-1996) - немецкий врач-токсиколог. Изучал химию в университетах Мюнхена и Вюрцбурга, а также медицину - в Берлине. Работал ассистентом Вернера Хаазе (нем. Karl Ludwig Werner Haase, 1903-1980) в лаборатории физиологической зоологии в Имперском биологическом институте сельского и лесного хозяйства (Biologische Bundesanstalt für Land- und Forstwirtschaft) в БерлинДалеме. В период Веймарской республики участвовал в работах по БОВ. В апреле 1936 - январе 1938 г. работал в 9-м отделе Управления вооружений сухопутных войск (Heereswaffenamt Wa Prüf 9), в феврале 1938 г. перешел в Военно-медицинскую академию, где возглавил Институт фармакологии и военной токсикологии. Считался крупнейшим в стране специалистом по боевым ОВ. В частности, под его руководством проводились первые испытания на людях табуна - речь шла об изучении воздействия на организм человека низких доз. В испытаниях участвовали добровольцы - военнослужащие, которым за участие в экспериментах платили. Табун В. Вирт испытывал также на себе. С июня 1941 г. - врио, с августа 1942 по август 1943 г. - начальник специальной учебно-научной группы Военно-медицинской академии. В июне 1945 г. был арестован, в декабре 1946 - августе 1947 г. допрашивался по «медицинскому делу». С 1948 г. работал в фармакологическом отделе Farbenfabriken Bayer A.G. в Вуппертале. Возглавлял отдел с 1954 г. и вплоть до своей отставки в 1963 г. 
Таблица 2 - Исследования, связанные с военно-химическим делом, в гражданских институтах Общества кайзера Вильгельма в период начионал-сочиализма [20, 21]

\begin{tabular}{|c|c|c|c|}
\hline Организация & Директор & Период & Характер исследований \\
\hline $\begin{array}{c}\text { Институт рабочей психологии } \\
\text { (нем. - KWI für Arbeitsphysiologie) } \\
\text { (филиал в Мюнстере) }\end{array}$ & $\begin{array}{c}\text { Эдгар Атцлер } \\
\text { (нем. - } \\
\text { Edgar Atzler, 1887-1938) }\end{array}$ & 1932-1934 & $\begin{array}{c}\text { - исследование пределов выносливости } \\
\text { военнослужащих при длительном ношении } \\
\text { противогазов GM } 24 \text { GM } 30 \\
\text { - эргономические недостатки конструкции } \\
\text { противогазов } \\
\text { - физиологические проблемы, связанные с длительным } \\
\text { ношением противогазов }\end{array}$ \\
\hline $\begin{array}{c}\text { Отдел генетики Института } \\
\text { изучения мозга } \\
\text { (нем. - KWI für Hirnforschung, } \\
\text { KWIHF) } \\
\text { (Берлин-Бух) }\end{array}$ & $\begin{array}{c}\text { Тимофеев- } \\
\text { Pесовский Н.B.' } \\
\text { (нем. - } \\
\text { Nikolai Timoféeff- } \\
\text { Ressovsky, 1900-1981) }\end{array}$ & 1939-1943 & $\begin{array}{c}\text { - проверка противогазовых фильтров (на } \\
\text { проницаемость) радиоактивными изотопами с } \\
\text { помощью генератора нейтронов «Philips» } \\
\text { - физиологические проблемы, связанные с длительным } \\
\text { ношением противогазов }\end{array}$ \\
\hline $\begin{array}{c}\text { Институт химии } \\
\text { (нем. - KWI für Chemie) } \\
\text { (Берлин-Далем) }\end{array}$ & $\begin{array}{c}\text { Отто Ган } \\
\text { (нем. - Otto Наhn, 1879- } \\
\text { 1968), Нобелевский } \\
\text { лауреат (1944) }\end{array}$ & 1940-1944 & $\begin{array}{c}\text { - исследование противогазовых фильтров методом } \\
\text { облучения радиоактивными изотопами }\end{array}$ \\
\hline $\begin{array}{c}\text { Институт изучения кожи } \\
\text { (нем. - KWI für Lederforschung) } \\
\text { (Дрезден) }\end{array}$ & $\begin{array}{l}\text { Вольфганг Грассман } \\
\quad \text { (нем. - } \\
\text { Wolfgang Grassmann, } \\
\quad \text { 1898-1978) }\end{array}$ & 1943-1944 & $\begin{array}{c}\text { - изучение воздействия противоипритных пропиток на } \\
\text { разные сорта кожи, используемые для изготовления } \\
\text { обмундирования и средств индивидуальной защиты } \\
\text { - средства дегазации, предназначенные для изделий из } \\
\text { кожи }\end{array}$ \\
\hline $\begin{array}{l}\text { Институт изучения течений } \\
\text { жидкости и газа } \\
\text { (нем. - KWI für } \\
\text { Strömungsforschung, KWIFD) } \\
\text { (Геттинген) }\end{array}$ & $\begin{array}{l}\text { Людвиг Прандтль } \\
\text { (нем. - } \\
\text { Ludwig Prandtl, 1875- } \\
\text { 1953) }\end{array}$ & $\begin{array}{c}\text { Январь - } \\
\text { сентябрь } \\
1943 \text { г. }\end{array}$ & $\begin{array}{c}\text { - изучение распространения и поведения паров ОВ на } \\
\text { море }\end{array}$ \\
\hline $\begin{array}{l}\text { Институт физической химии и } \\
\text { электрохимии (Берлин-Далем) }\end{array}$ & $\begin{array}{c}\text { Герхарт Яндер } \\
\text { (нем. - Gerhart Jander, } \\
\text { 1892-1961) } \\
\text { (временный директор } \\
\text { 1933-1934) } \\
\text { Петер Адольф Тиссен } \\
\text { (нем. - Peter Adolf } \\
\text { Thiessen, 1899-1990) } \\
\text { (1934-1945) }\end{array}$ & 1933-1945 & $\begin{array}{c}\text { - аэрозоли (дымы, туманы) } \\
\text { - фильтры для противогазов } \\
\text { - детекторы } \\
\text { - поиск новых ОВ и зажигательных средств (трифторид } \\
\text { хлора, N-Stoff) } \\
\text { - физиологическое действие OB }\end{array}$ \\
\hline $\begin{array}{c}\text { Институт химии при Институте } \\
\text { медицинских исследований } \\
\text { (нем. - Institut für Chemie des } \\
\text { KWI für medizinische Forschung, } \\
\text { KWIMR) } \\
\text { (Гейдельберг) }\end{array}$ & $\begin{array}{c}\text { Рихард Кун } \\
\text { (нем. - } \\
\text { Richard Kuhn, 1900- } \\
\text { 1967), } \\
\text { Нобелевский лауреат } \\
\text { (1939) }\end{array}$ & 1941-1945 & $\begin{array}{c}\text { - ОВ нервно-паралитического действия и антидоты } \\
\text { (а) синтез } \\
\text { (b) физиологическое действие (опыты на животных и } \\
\text { тканях мозга человека) } \\
\text { - препараты для лечения ожогов кожных покровов } \\
\text { ипритом (Lost) }\end{array}$ \\
\hline \multicolumn{4}{|c|}{$\begin{array}{l}\text { ' Советский ученый-биолог и генетик Николай Владимирович Тимофеев-Ресовский в } 1925 \text { г. офичиально переехал на работу } \\
\text { в Германию по приглашению Общества кайзера Вильгельма и с согласия советских властей. В конце 1930-х годов отказался } \\
\text { возвращаться в СССР, опасаясь ареста, и всю войну провел в Германии. Возвращен в } 1945 \text { г. }\end{array}$} \\
\hline
\end{tabular}

\section{(Anatomisches Institut) ${ }^{8}$ Страсбургского рейх- суниверситета (Reichsuniversität Straßburg) ${ }^{9}$}

8 В принципе, это была обычная «анатомичка», куда студентов-медиков водили изучать и сдавать анатомию в первом (зимнем) семестре. Только при А. Хирте трупы туда доставляли - из хосписов, тюрем, концентрационных лагерей - в частности, из Нацвайлера, а также из госпиталей для военнопленных. Их в Эльзасе было два - для польских, советских и итальянских военнопленных. В частности, в годы Второй мировой войны в Анатомический институт «для использования в образовательных целях» было направлено как минимум 230 тел советских военнопленных, скончавшихся в госпиталях от ранений и болезней, а также от ненадлежащего ухода. Отправляли в этот институт и погибших в результате опытов с боевыми ОВ - в частности, после опытов с ипритом, которые А. Хирт проводил в Нацвайлере с ноября 1942 г., погибли трое заключенных немцев Фридрих Трис (Friedrich Tries), Карл Кирн (Karl Kirn) и Вильгельм Мюссген (Wilhelm Müssgen). Их тела разобрали на органы и 11 января 1943 г. отправили в институт для последующего изготовления гистологических препаратов [18, 19].

9 Исследование воздействия БОВ на человеческий организм не было основной сферой деятельности А. Хирта, который после опытов с ипритом переключился на более «перспективное» по тем временам направление исследований - «расовую антропологию», которая должна была служить обоснованием нацистских 


\section{$[18,19]$ (рисунок 5).}

Кроме того, в работах по химическому оружию и средствам медицинской защиты было в той или иной степени задействовано семь из почти сорока существовавших в 1930-1940-е гг. научно-исследовательских институтов (НИИ) и организаций Общества кайзера Вильгельма крупнейшей научно-исследовательской структуры вне системы университетов [20]. Если в Первую мировую войну ИФХЭ был, по сути, головной структурой, то впоследствии исследования стали вестись децентрализованно ${ }^{10}$ [21].

Часть институтов Общества, как показано в таблице 2, работала на основе разовых программ и краткосрочных контрактов, поскольку по характеру своей основной деятельности они не были связаны ни с химией, ни с медициной. Они решали конкретно-практические задачи, которые перед ними ставили военные.

Для других организаций - ИФХЭ ${ }^{11}$ и Института химии при Институте медицинских исследований в Гейдельберге - химическое оружие и средства защиты от него были основными направлениями исследований. Там были сформированы специальные отделы. ИФХЭ до конца войны - возглавлял Петер Адольф Тиссен, после войны - активный участник программы по созданию первой советской атомной бомбы (рисунок 6).

В частности, в Институте химии при Институте медицинских исследований под руководством Рихарда Куна вели работы по изучению табуна, а затем зарина и зомана, а также по поиску антидотов к ним. Испытания физиологического действия фосфорорганических ОВ проводили на животных и тканях мозга человека (рисунок 7).

В сравнении с работами на чисто военных объектах, исследования в НИИ Общества

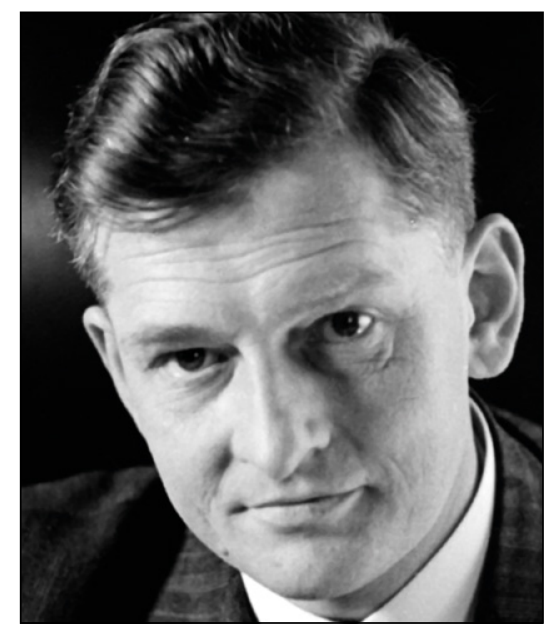

\section{Рисунок 7 - Рихард Кун \\ (URL: https://www.nobelprize.org/prizes/ chemistry/1938/kuhn/facts/; дата обращения: 13.06 .2021 )}

кайзера Вильгельма были достаточно скромными и проводились в гораздо меньших масштабах. Тем более, что начиная с 1935 г. роль главных центров военной химии постепенно перешла к лаборатории противохимической защиты в Шпандау и испытательному полигону в Мюнстере. В Шпандау перевели и часть сотрудников ИФХЭ.

Тем не менее, гражданские структуры все время работали в тесной связке с военными, а ученые, работавшие в одной и той же сфере, прекрасно знали друг друга и поддерживали тесные академические и личные контакты.

Кроме военных структур, НИИ и университетов, различные исследования велись в лабораториях при предприятиях и частных фирмах химической и фармацевтической промышленности - в частности, в концернах в составе I.G.

расовых теорий. Изначально он намеревался собрать коллекцию черепов представителей разных антропологических типов, но впоследствии переключился на «коллекционирование» именно евреев - выходцев из разных стран, в том числе из СССР. В августе 1947 г., на Нюрнбергском процессе над врачами (над медицинскими чиновниками Третьего рейха и врачами из концлагерей), обвиняемыми в медицинских преступлениях, сбор экспонатов для антропологической коллекции А. Хирта (то есть убийство военнопленных и заключенных специально для пополнения коллекции черепов) был признан военным преступлением и преступлением против человечности. Сам А. Хирт до суда не дожил - после освобождения Страсбурга союзными войсками бежал в Шварцвальд и застрелился, причем не из-за того, что испугался ответственности или его замучила совесть, а потому, что погибла «уникальная коллекция».

10 Это обстоятельство отчасти было связано с расширением круга научно-практических проблем, которые так или иначе приходилось решать, а также с усложнением задач в целом, что требовало привлечения специалистов из самых разных областей, а также применения междисциплинарных подходов. Отчасти такая децентрализованная система сложилась в годы Веймарской республики из-за необходимости обходить версальские ограничения. Рейхсвер предпочитал иметь дело с отдельными институтами, небольшими лабораториями и маленькими фирмами. Так проще было и замаскировать истинные цели той или иной работы, и обеспечить секретность.

11 Вскоре после прихода к власти НСДАП и принятия в апреле 1933 г. «Закона об ограничениях в профессиональной гражданской службе» в ИФХЭ начались кадровые перестановки. Ф. Габер, будучи евреем, в ноябре 1933 г. вынужден был покинуть пост директора института. Вместе с ним ушли еще 29 сотрудников. На руководящие посты пришли немцы и члены НСДАП, которые привели в ИФХЭ своих специалистов. 


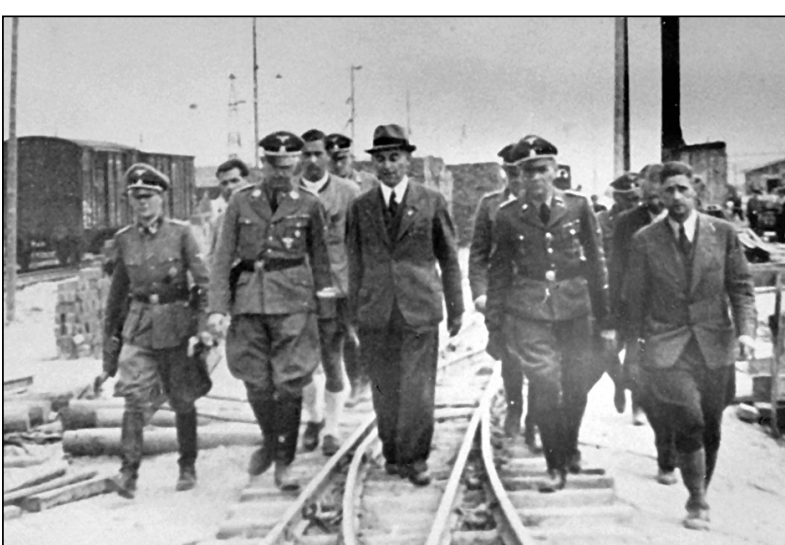

Рисунок 8 - Крупнейший в Германии конгломерат кончернов химической и фармачевтической промышленности IG Farben в годы Bmорой мировой войны размещал производство в концентрационных лагерях. Испытания отравляющих веществ и антидотов проводили на заключенных. На фотографии - рейхсфюрер СС Г. Гиммлер посещает строящийся завод IG Farben nо производству синтетического каучука. Аушвич-ІІІ Моновиц-Буна, 17-18 июля 1942 г. Слева направо - Р. Брандт, рейхсфюрер СС

Г. Гиммлер, инженер IG Farben и руководитель строительных работ объекта МоновицБуна Макс Фауст (нем. - Max Faust, 1891-1980) u комендант Аушвица Рудольф Хёсс (нем. - Rudolf

Franz Ferdinand Нӧß, 1900 - 16 апреля 1947 г., казнен за военные преступления) (URL: https:// collections.ushmm.org/search/catalog/pa1036470; дата обращения: 13.06.2021)

Farben (Interessen-Gemeinschaft Farbenindustrie $\mathrm{AG})^{12}[22]$ (рисунок 8).
Эти исследования по своим целям и задачам были сугубо гражданскими, не имевшими никакого отношения к боевым ОВ. Однако, согласно правительственному указу от 1935 г., обо всех инновациях, которые потенциально могли иметь военное значение, следовало сообщать в Военное министерство ${ }^{13}$.

Таким образом, широко проведенные исследования по БОВ, наличие научной и промышленной базы позволили Германии создать и произвести химическое оружие - БОВ в промышленных масштабах, а также средства его применения.

Так, в годы Второй мировой войны химическая промышленность Германии, переориентированная на военное производство, произвела порядка 977 тыс. 500 метрических тонн взрывчатых веществ (на 28 предприятиях), 974 тыс. метрических тонн порохов (на 43 предприятиях), а также 69 тыс. 500 метрических тонн боевых отравляющих веществ ${ }^{14}$ (на 10 предприятиях) и порядка 805 тыс. метрических тонн прекурсоров [23, 24].

Объемы производства БОВ на немецких предприятиях в годы Второй мировой войны показаны в таблице 3.

Основное количество БОВ составили сернистые и азотистые иприты, а также фосген-дифосген и арсины [23]. Одновременно были разработан новый класс БОВ - фосфорорганические.

В итоге, в годы Второй мировой войны Германия обладала полным арсеналом артиллерийских и авиационных боеприпасов [26]. На вооружении Вермахта стояли химические мины и снаряды 7,5-см, 10,5-см, 15-см и 21-см

\begin{abstract}
12 В годы войны I.G. Farben выполняла военные заказы и размещала производство в концлагерях, в частности, в Аушвице-Биркенау. После войны был даже организован специальный судебный процесс - Нюрнбергский процесс по делу I.G. Farben (официальное название - «Соединенные Штаты Америки против Карла Крауха и других», англ. - The United States of America vs. Carl Krauch, et al.) - шестой по счету процесс американского военного трибунала в Нюрнберге из 12 проведенных властями США в своей зоне оккупации Германии. Судебное разбирательство длилось с 14 августа 1947 г. по 30 июля 1948 г. 24 члена совета директоров и должностных лица I.G. Farben обвинялись в массовых убийствах, использовании принудительного труда и других преступлениях против человечности. 13 обвиняемых были осуждены на различные сроки тюремного заключения, 10 - оправданы и одному не был вынесен приговор по состоянию здоровья. Дополнительным решением суда предусматривалось разделение конгломерата I.G. Farben на BASF, Bayer и Hoechst.

13 Именно это и сделало руководство лаборатории корпорации I.G. Farbenindustrie в Леверкузене в 1937 г. Там проводили исследования фосфорорганических соединений на предмет их возможного использования в качестве сельскохозяйственных пестицидов. Однако после того, как в январе 1937 г. руководитель лаборатории Герхард Шрадер (нем. - Gerhard Schrader, 1903-1990) получил тяжелое поражение синтезированным им же новым соединением, а токсикологические исследования на животных, проведенные в лаборатории коммерческой гигиены I.G. Farbenindustrie в Эльберфельде, подтвердили его высокую токсичность для теплокровных - следовательно, и для людей, в I.G. Farbenindustrie поняли, что коммерческого интереса оно не представляет ввиду невозможности его безопасного использования, и отправили соответствующий рапорт в Управление сухопутных войск. Там, разумеется, заинтересовались, а сам Г. Шрадер вскоре перешел на работу в Шпандау. Соединение получило кодовое название «трилон» (табун).

${ }^{14}$ Строго говоря, точное количество ОВ и ХО, произведенных в Германии в годы Второй мировой войны, установлению уже, скорее всего, не подлежит. Во-первых, под конец войны немцы начали уничтожать не только само XО, но и всю документацию по нему. Во-вторых, уже после войны союзники в силу различных причин иногда жонглировали данными. Этим, в частности, объясняется периодически встречающаяся в разных источниках разница в цифрах объемов производства основных БОВ.
\end{abstract}


Таблица 3 - Объемы производства боевых отравляющих веществ на немецких предприятиях в годы Второй Мировой войны [24]

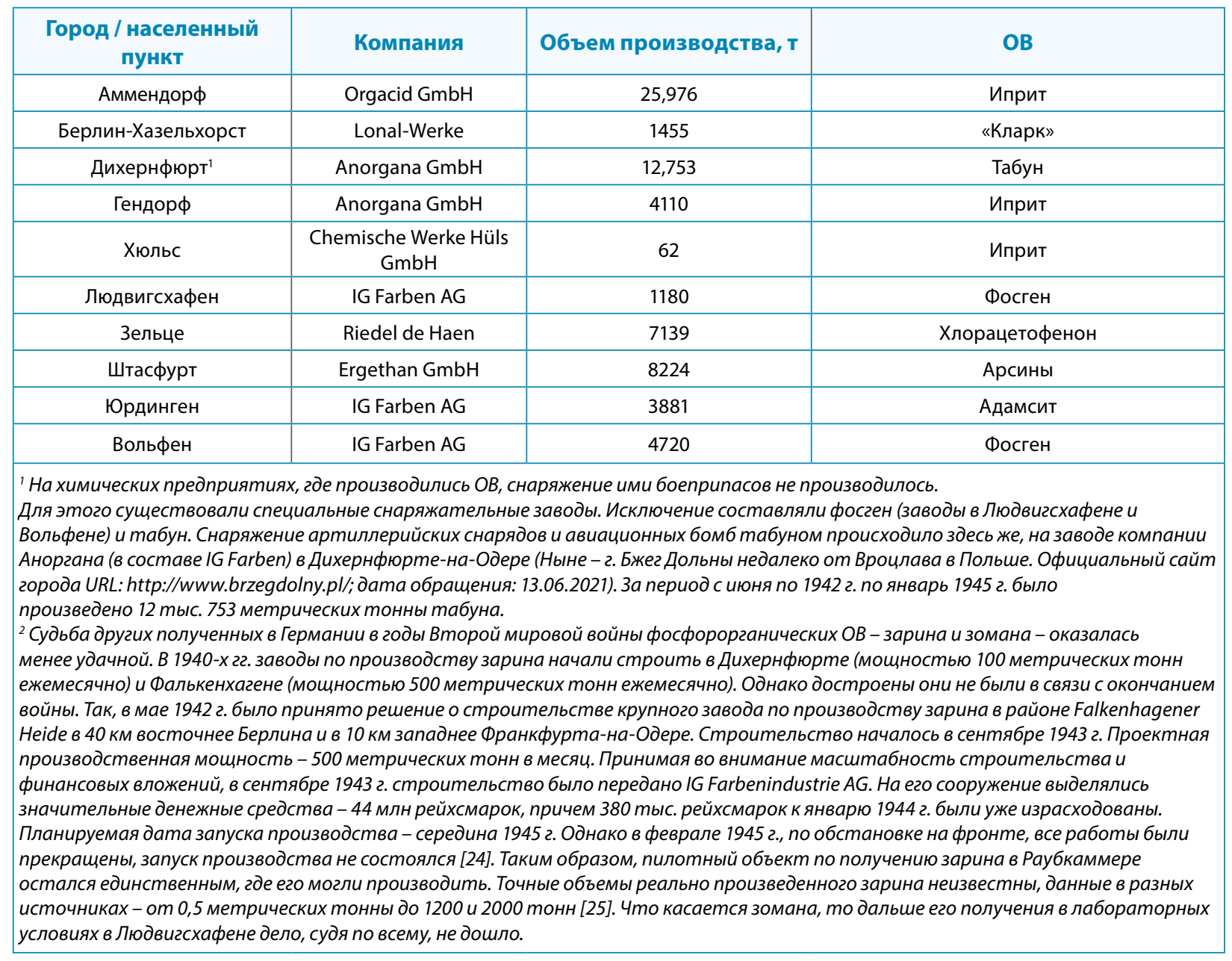

калибров, ракеты и минометные снаряды 8-см, 10-см и 15-см калибров, а также авиационные бомбы массой 50, 250 и 500 кг (в снаряженном состоянии) [27], в том числе в снаряжении табуном (рисунок 9).

Таким образом, Германия сумела не только восстановить, но и подтвердить научное и военно-промышленное превосходство над своими противниками в военно-химическом деле, а в определенном смысле и превзойти их [15]. Если бы немцы действительно масштабно применили на фронтах Второй мировой войны тяжелые 250-килограммовые авиационные бомбы с табуном, союзникам нечем было бы от них защититься и нечего им противопоставить ${ }^{15}$.
Испытания на людях в 1933-1945 г2. Испытания БОВ, изучение их физиологических и токсикологических свойств, а также средств и схем лечения поражений проводили сначала на мелких (мыши, крысы) и крупных (кролики, обезьяны) животных, а затем на людях. Для этих целей в Военно-медицинской академии и цитадели в Шпандау были сооружены газовые камеры. Участниками опытов первоначально были добровольцы сами ученые, а также военнослужащие и курсанты военно-учебных заведений, которые осознавали возможную угрозу жизни и здоровью ${ }^{16}$. Военнослужащим, кроме того, за участие в экспериментах платили от 5 до 100 рейхсмарок.

15 Военные доктрины всех ведущих европейских стран предусматривали неприменение химического ору-
жия первыми, но допускали его ответное применение - в полном соответствии с позициями этих стран при
ратификации Женевского протокола о запрещении применения на войне удушливых, ядовитых или других
подобных газов и бактериологических средств (1925). То же касалось и Германии.
${ }^{16}$ В той степени, разумеется, в какой об этой угрозе были осведомлены сами токсикологи, чтобы проинфор-
мировать о ней участников экспериментов. Это соображение было особенно актуально для табуна. Его про-
изводство в промышленных масштабах уже шло на заводе в Дихернфюрте, а ученые еще только пытались
его исследовать. В частности, в результате опытов в Шпандау и Эльберфельде были определены летальные 


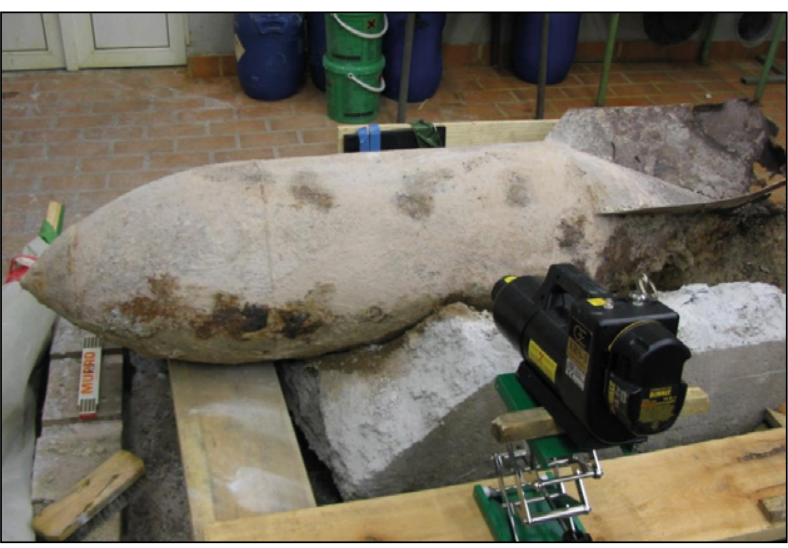

Рисунок 9 - Тяжелая авиабомба 250 кг времен Второй мировой войны на объекте УХО GEKA, Мюнстер [28]

Этическая сторона вопроса регулировалась выпущенным еще 28 февраля 1931 г. рейхсминистерством внутренних дел «Положением о новой терапии и опытах на людях», согласно которому «новая терапия может осущеесвляться только после того, как объект или его законный представитель недвусмысленно согласился на проиедуру в свете соответствующей информации, которая ему была заранее предоставлена» [29]. Поводом для появления этого документа стала гибель 77 новорожденных после прививки вакциной от туберкулеза («трагедия в Любеке») ${ }^{17}$.

Положение признавало невозможность полностью обойтись без испытаний вновь создаваемых лекарственных средств или схем лечения тех или иных заболеваний на людях. Вместе с тем оно налагало на авторов экспериментов, проводимых с чисто исследовательскими целя- ми, а не в целях профилактики и/или лечения, ответственность за жизнь и здоровье тех, кто этим экспериментам подвергался. При этом все время предлагалось учитывать как возможную пользу от эксперимента, так и возможный вред конкретным людям. В документе было указано, что опыты на людях могут быть поставлены только на завершающем этапе, после лабораторных испытаний и опытов на животных. Если опытами на животных можно было обойтись, опыты на людях запрещались. Для их проведения необходимо было заручиться недвусмысленным информированным согласием участников или их законных представителей ${ }^{18}$. Обо всех негативных последствиях следовало предупреждать заранее. Опыты с чисто исследовательскими целями на детях и на несовершеннолетних запрещались безусловно. Также признавались несовместимыми с этическими принципами и, соответственно, запрещались испытания на умирающих [30].

Это положение было действующим все годы Второй мировой войны. Формально его никто не отменял.

Однако, начиная с 1933 г. во всех научно-исследовательских структурах как военных, так и гражданских, начались проблемы с лабораторными животными. В 1933 г. в Германии был принят специальный зоозащитный закон, серьезно ограничивший возможность проведения опытов на животных. Затем весной 1939 г. военно-медицинская служба (санитарная инспекция) Вермахта запретила использовать животных для опытов везде, кроме научных лабораторий, которые постоянно подвергались проверкам. В результате к началу Второй мировой войны работы у уче-

токсодозы, но - для животных. Для людей их установить еще только предстояло. Известно, что опыты на людях (с низкими дозами) ставил В. Вирт. Кроме того, аналогичные опыты ставились в лаборатории I.G. Farbenindustrie в Эльберфельде, причем с более высокими дозами. Полученные ими результаты были в любом случае оценочными - доведение испытуемых до летального исхода не могло быть условием опытов, когда они проводились на добровольцах, а сведений об опытах с табуном в концлагерях, где с «биоматериалом» можно было не церемониться, нет, причем скорее всего, их и не было.

${ }^{17}$ В 1930 г. в Любеке (Шлезвиг-Гольштейн) началась масштабная программа вакцинации населения против туберкулеза. В программе использовалась французская вакцина BCG (Bacille Calmette-Guérin), изготовленная из штамма ослабленной живой коровьей туберкулезной палочки. Она была разработана в 1905-1921 гг. французскими бактериологами Альбером Кальметом (фр. - Albert Calmette, 1863-1933) и Камилем Гереном (фр. - Camille Guérin, 1872-1961). В 1921 г. она была одобрена парижским Институтом Пастера. Там же ее протестировали на 120 новорожденных младенцах, находившихся в группе риска по туберкулезу - их родители уже были больны. Эксперимент был признан успешным. Однако он был не совсем репрезентативным, поскольку только в 24 семьях, откуда брали детей на вакцинацию, имелись больные с открытой формой туберкулеза. В Любеке врачи сделали прививки вакциной BCG 256 10-дневным новорожденным и случилась трагедия - все привитые заболели, а 77 детей погибли. Разразился скандал. Последовал суд, на котором были обвинены трое врачей и медсестра. Расследование показало, что в трагедии виновата немецкая лаборатория, где вакцина была изготовлена - она оказалась зараженной вирулентным штаммом, который хранился в том же инкубаторе. Директор лаборатории был осужден за халатность. Однако после «трагедии в Любеке» вакцина BCG была в Германии запрещена вплоть до конца Второй мировой войны.

${ }^{18}$ Применение «новой терапии» без согласия пациента разрешалось только в том случае, когда речь шла об использовании недостаточно испытанных лекарственных средств в экстренных, жизнеугрожающих ситуациях, а также если заблаговременное согласие нельзя было получить в силу особых обстоятельств. 
ных стало больше, а лабораторных животных - меньше.

Это обстоятельство, вкупе с закрытостью всех исследований по БОВ, а также определенными идеологическими настроениями среди самих ученых способствовало переносу испытаний в концентрационные лагеря - на «биологический материал», на который соображения гуманизма в данную минуту не распространялись. Или они были направлены на другие объекты.

Испытания на людях в кониентрационных лагерях. Уже после Второй мировой войны в руки британских спецслужб попали сведения о том, что сравнительные исследования ингибирующего воздействия фосфорорганических ОВ, в частности, зарина, на холинэстеразу человека проводили в Институте медицинских исследований Общества кайзера Вильгельма. Для исследований использовались, наряду с животными (крысами, кроликами, собаками, кошками и лошадьми), ткани человеческих органов, в частности, печени. Сам Р. Кун впоследствии утверждал, что в институте имели дело исключительно с трупами утопленников, у которых органы изымались в течение 24 ч после смерти. Однако в руки британских спецслужб попал документ, датирующийся 8 апреля 1943 г., содержащий пометку секретаря Общества кайзера Вильгельма Эрнста Телшова (нем. - Ernst Telschow, 1889-1988), сделанную после посещения Гейдельберга. В ней говорилось: «Проф. Кун сейчас ставит очень интересные опыты, для которых ему нужны ткани мозга молодых и здоровых людей. Я пообещцал ему, что буду ходатайствовать по этому вопросу перед соответствуюшими властями». 22 апреля 1943 г. Э. Телшов направил Р. Куну личное письмо, в котором сообщил, что обращался по его вопросу к ряду высокопоставленных чиновни- ков в Министерстве юстиции с ходатайством о предоставлении запрошенных органов. За транспортом было предложено обращаться к военным. Никаких других документальных данных о продолжении этого сюжета не сохранилось. Можно лишь предполагать, откуда можно было в 1940-х годах взять органы «молодых, здоровых людей» в рамках пенитенциарной системы - тюрьмы и лагеря. Речь могла идти: о жертвах программ эвтаназии (этим источником иногда пользовались в других институтах Общества); о заключенных концентрационных лагерей (пока они были еще относительно здоровы); о лицах, приговоренных к смертной казни - после или вместо нее ${ }^{19}$. Точных сведений о характере предполагаемых «очень интересных опытов» тоже не сохранилось, однако, скорее всего, речь шла об исследовании нейротоксичности фосфорорганических ОВ и об изучении воздействия ФОВ на ЦНС [10].

В силу целого ряда причин, данных ${ }^{20}$ об испытаниях БОВ в концлагерях сохранилось очень мало. В частности, после войны появилась информация о якобы имевших место испытаниях табуна на заключенных лагеря Гросс-Розен возле Дихернфюрта-на-Одере. В Дихернфюрте находился завод компании "Anorgana GmbH», где с 1942 г. запустили производство табуна и снаряжение им боеприпасов. Известно, что заключенные Гросс-Розена работали там наравне с немецкими рабочими - вольнонаемными. Известно, что средства защиты были недостаточными. Известно, что на заводе периодически происходили несчастные случаи, в том числе с летальным исходом. После войны свидетели подтвердили случаи лечения пострадавших на заводе атропином ${ }^{21}$. Но были ли эти поражения вызваны несчастными случаями на опасном производ-

\footnotetext{
${ }^{19}$ Из документов по «медицинскому делу» известно, что в ряде случаев для медицинских опытов над людьми использовали лиц, приговоренных к смертной казни по тем или иным политическим или уголовным обвинениям, причем участие в опытах рассматривалось как своего рода замена. В частности, в письме А. Хирту от 3 января 1942 г. В. Зиверс, затребовав от А. Хирта более подробные сведения о характере его деятельности для последующего доклада Г. Гиммлеру, сообщил: «Что касается ваших антропологических исследований, то я уже сейчас могу проинформировать Вас, что Рейхсфюрер СС даст Вам возможность проводить любые эксперименты, которые могут помочь Вам в Ваших исследованиях, на заключенных и настоящзх преступниках, которые никогда и ни при каких условиях освобождены не будут, а также на лицах, приговоренных к смертной казни» (URL: https://nuremberg.law.harvard.edu/documents/204-letter-to-dr-hirth?q=Hirth\#p.1; дата обращения: 13.06.2021).

20 Первая причина лежит на поверхности - все работы изначально велись в режиме секретности. В конце войны документы и другие доказательства массово уничтожались самими немцами. Вторая, менее очевидная - то, что осталось, было не уничтожено, а наоборот, тщательно сохранено и засекречено победителями. В частности, материалы по «медицинскому делу» опубликованы американской стороной с заметными лакунами. Причины тоже очевидны - врачей осудили, а вот конкретные результаты их опытов победителям были и самим интересны.

21 После войны бывший заключенный Тадеуш Кароль (Tadeusz Karol), работавший на этом заводе, показал, что однажды ему приказали без средств защиты войти в снаряжательный цех, чтобы проверить наличие утечек OB и заражение цеха табуном. Он получил поражение и потерял сознание. Лечили его атропином. Очевидно, в данном случае шла речь о преднамеренном использовании человека в качестве «живого газосиг-
} 


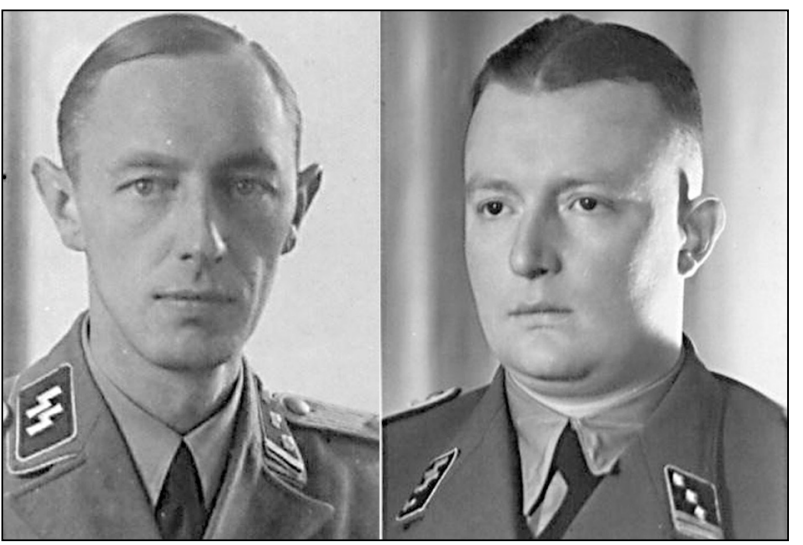

Рисунок 10 - Слева Вальтер Зоннтаг (нем. - Walter Sonntag, 1907-1948, казнен за военные преступления), справа Уго Хайни Шмик [31]

стве или преднамеренными опытами, проводившимися на регулярной основе, до сих пор точно не известно и не доказано [31].

Концентрационный лагерь Заксенхаузен. Непосредственным поводом для интенсификации работ по БОВ и средствам лечения поражений стали следующие события. 8 сентября 1939 г., через неделю после начала вторжения Вермахта в Польшу, польские войска во время отступления при попытке взорвать мост в городе Ясло (ныне - в Подкарпатском воеводстве) по ошибке использовали не обычные мины, а ипритные. В результате поражения получили 14 солдат Вермахта, двое погибли. После этого А. Гитлер издал специальное распоряжение о начале подготовки к «газовой войне».

После этого Военно-медицинская академия при участии СС организовала несколько серий испытаний протоколов и средств лечения поражений кожных покровов сернистым ипритом.

По крайней мере две серии таких испытаний были проведены в концлагере Заксенхаузен ${ }^{22}$ (Ораниенбург, земля Бранденбург) в октя- бре-декабре 1939 г. на 31 заключенном, которым наносили на кожу иприт и ждали развития поражений. Затем пораженные участки обрабатывали разными препаратами из числа общедоступных антибактериальных средств и средств лечения ожогов, в частности, фресканом (кодовое название F 1000 и F 1001 - порошок производства компании Dr. Fresenius) $)^{23}$ и тиосептом ${ }^{24}$.

Опыты ставили заведующий хирургическим отделением Заксенхаузена Уго Хайнц Шмик (нем. - Hugo-Heinz Schmick, 1909-1982) (член НСДАП с августа 1933 г., СС - с мая 1933 г.) и лагерный врач Вальтер Зоннтаг, тоже из СС (рисунок 10).

Первая серия опытов состоялась 13 октября 1939 г. В ней участвовали 23 заключенных. Им наносили на кожу рук иприт, а потом обрабатывали волдыри антибактериальными средствами. Ход эксперимента тщательно документировался и снимался на кинопленку. Во второй серии, состоявшейся в декабре 1939 г., участвовали 8 заключенных. Им нанесли иприт на кожу обеих рук, а через три дня, после того, как пораженные участки покрылись волдырями с экссудатом (в некоторых случаях их размер достигал размеров $7 \times 18$ см), волдыри вскрыли и в открытые раны занесли бактериальную инфекцию - бактерии стрептококков, стафилококков и пневмококков. Лечили антисептиками. У тех, кому занесли инфекцию, развился сепсис. Схемы лечения антисептиками не работали. В январе 1940 г. рейхсфюреру СС Генриху Гиммлеру (нем. - Heinrich Himmler, 1900-1945) было доложено о неудаче экспериментов.

В то же самое время, когда СС проводила опыты на заключенных Заксенхаузена, тот же самый фрескан испытывали на людях в Военно-медицинской академии. Авторами экспериментов были директор Института фармакологии при Университете Мюнстера Людвиг Лендле (нем. - Ludwig Lendle, 1899-1969) и директор

нализатора», причем если учесть, что речь шла о заключенном концлагеря, можно предположить, что о добровольности в данном случае речь не шла и выбора у него особо не было. Однако такой случай - едва ли не единственный, о котором стало известно [31].

22 Расположен неподалеку от Берлина. Официально открыт в сентябре 1936 г. В апреле 1938 г. была создана Немецкая компания земляных и каменоломных работ (DEST - Deutsche Erd- und Steinwerke GmbH), первоначальной целью которой было обеспечение планов А. Гитлера и Альберта Шпеера (нем. - Albert Speer, 19051981, личный архитектор Гитлера, в 1942-1945 гг. рейхсминистр вооружения и военного производства) по перестройке Берлина и других немецких городов. Именно для снабжения предприятия рабочей силой вблизи каменных карьеров были созданы Маутхаузен и Флоссенбург, Нойенгамме - филиал Заксенхаузена, а рядом с Бухенвальдом и Заксенхаузеном появились кирпичные заводы. Со 2 августа 1938 г. в Заксенхаузене располагалась главная руководящая инстанция - Инспекция концентрационных лагерей [32].

${ }^{23}$ Фрескан - антибактериальный препарат в виде порошка, использовавшийся в противоожоговой терапии, производства компании Dr.Fresenius (Бад Хомбург) (URL: https://www.fresenius.com/index, дата обращения: 13.06.2021). В настоящее время компания является одним из крупнейших в мире производителей медицинского оборудования, в первую очередь для гемодиализа почек. Работает, в том числе, в России - URL: https:// www.freseniusmedicalcare.ru/ru/glavnaja-stranica/ (дата обращения: 13.06.2021).

24 Тиосепт - сульфобитуминат аммония (ихтиол). CAS 8029-68-3.

URL: https://www.chembk.com/en/chem/thiosept (дата обращения: 13.06.2021). Мазь бактериостатического и противовоспалительного действия. 
Института фармакологии и военной токсикологии Военно-медицинской академии В. Вирт. В опытах участвовали 23 военнослужащих, которым наносили на кожу рук иприт. Результат оказался аналогичным - нулевым. Ожоги у подопытных зажили спустя 6-8 недель.

Впоследствии было доказано, что военные врачи Л. Лендле и В. Вирт не только были осведомлены об опытах своих «коллег» из СС в Заксенхаузене, но и ориентировались на их результаты. Кроме того, В. Вирт специально ездил в Заксенхаузен знакомиться с результатами опытов. Ему показали «шесть или десять человек с ожогами на руке, величиной приблизительно с ладонь». Там же ему продемонстрировали отснятый на кинопленку материал, отснятый во время этих испытаний. Разницы между теми, кого лечили антисептиками, и теми, кого не лечили вообще, он на этих кадрах не увидел.

Концентрационный тагерв Нацвайлер 25. Опыты с ипритом Августа Хирта. В период с 1942 по 1944 г. серию опытов с ипритом

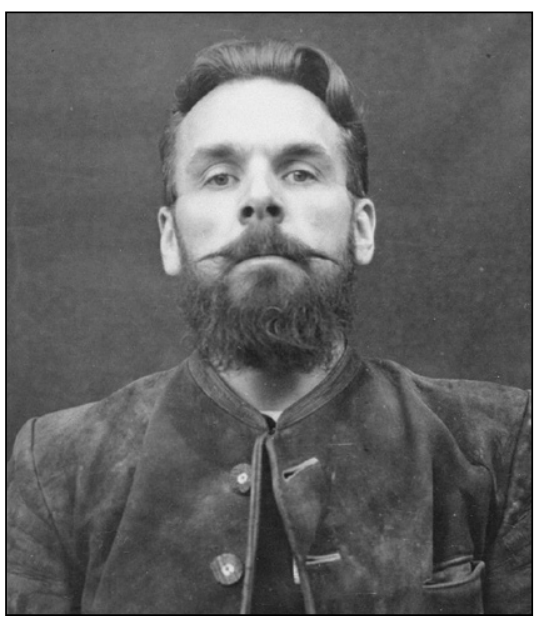

Рисунок 11 - Вольфрам Зиверс (нем. - Wolfram Sievers, 1905-1948, казнен за военные преступления и преступления против человечности) (URL: https://www.ushmm.org/information/ exhibitions/online-exhibitions/special-focus/ doctors-trial/indictment/defendants; дата обращения: 13.06.2021)

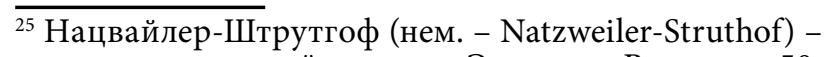

концентрационный лагерь в Эльзасе в Вогезах в 50 км юго-западнее Страсбурга. Представлял собой целую систему из порядка 50 лагерей, подчиненных главному, расположенных на границе между Францией и Германией на территории Эльзаса и Лотарингии (Франция) и Бадена и Вюртемберга (Германия). Система лагерей стала создаваться здесь вскоре после оккупации немецкими войсками Страсбурга и аннексии Эльзаса весной 1940 г. Первоначально соорудили небольшой лагерь по типу тюрьмы, рассчитанный на 150 человек и предназначенный для политических заключенных, бойцов Сопротивления и лиц, попавших под так называемый «защитный арест». Он располагался рядом с городком Шмирек в 50 км. от Страсбурга и получил название Шмирек-Форбрюк (нем. - Schirmeck-Vorbrück, фp. - Schirmeck-La Broque). Первыми заключенными в нем стали эльзасские антифашисты. Лагерь функционировал в течение всей войны как трудовой. В нем, помимо политических заключенных и членов их семей, содержались эльзасцы, пытавшиеся перейти новую границу и уйти во Францию, члены секты «Свидетели Иеговы», а также лица, обвинявшиеся в спекуляции и в уголовных преступлениях. За охрану и порядок отвечала немецкая «Полиция порядка» (нем. - Ordnungspolizei, Orpo). Через несколько месяцев после образования Шмирека неподалеку от него, возле деревни Нацвайлер, СС начала строительство другого лагеря. Приказ о его образовании издал лично рейхсфюрер СС Г. Гиммлер. Место было выбрано не случайно - неподалеку находились гранитные каменоломни, которые были экспроприированы принадлежавшей SS компанией SS-Deutsche Erd und Steinwerke GmbH (DEST) по производству строительных материалов для государственных строительных проектов, которая начала их разработку (помимо Нацвайлера, DEST имела свои производства в Заксенхаузене, Бухенвальде, Флоссенбурге, Маутхаузене, Гросс Розене и Нойенгамме). Рядом находился зимний горнолыжный курорт Штрутгоф. Официальная дата образования лагеря - 1 мая 1941 г., но работы по его строительству начались в апреле 1941 г. Для сооружения бараков использовали заключенных из Шмирека. Первая партия заключенных - 150 человек - прибыла 21 мая 1941 г. из Заксенхаузена. Заключенные, которых стали привозить партиями из других лагерей, занимались постройкой лагеря, но главным образом работали в каменоломнях. Вплоть до весны 1942 г. концлагерь Нацвайлер оставался сравнительно небольшим, в нем содержалось не более 200 человек. Однако к концу года в нем было зарегистрировано уже около 2000 человек. К 1943 г. лагерь состоял из 17 блоков в границах лагеря, и 12 - за его пределами. В него стали привозить заключенных крупными партиями из Германии, Норвегии и других европейских стран. В июне 1943 г. в Нацвайлере было зарегистрировано уже 4430 заключенных. В 1944 г. их численность колебалась в пределах 6000-7000 человек. Всего же в лагере и в бараках за его пределами было зарегистрировано 52000 человек. В лагере был достаточно высокий уровень смертности. По оценочным данным, от истощения и болезней погибли около 20000 человек. Сюда свозили заключенных со всей Европы. Женщин в лагере не было. Большинство заключенных - политические. Главному лагерю подчинялись свыше 40 вспомогательных лагерей. Их число постоянно росло, причем некоторые даже не успели достроить к осени 1944 г., когда главный лагерь был эвакуирован. Лагерь был трудовым, заключенные работали, главным образом, в гранитных каменоломнях и на дорожно-строительных работах. Осенью 1943 г. там основала производство и ремонтные мастерские авиастроительная компания «Junkers», для нее были построены два здания и 13 бараков. Заключенные, а также вольнонаемные рабочие, ремонтировали авиационные двигатели. Собственного крематория в лагере первоначально не было, тела умерших или погибших сжигали в передвижном крематории, но в октябре 1943 г. для этих целей построили собственный. Кроме того, в Нацвайлере была сооружена газовая камера - специально для медицинских экспе- 


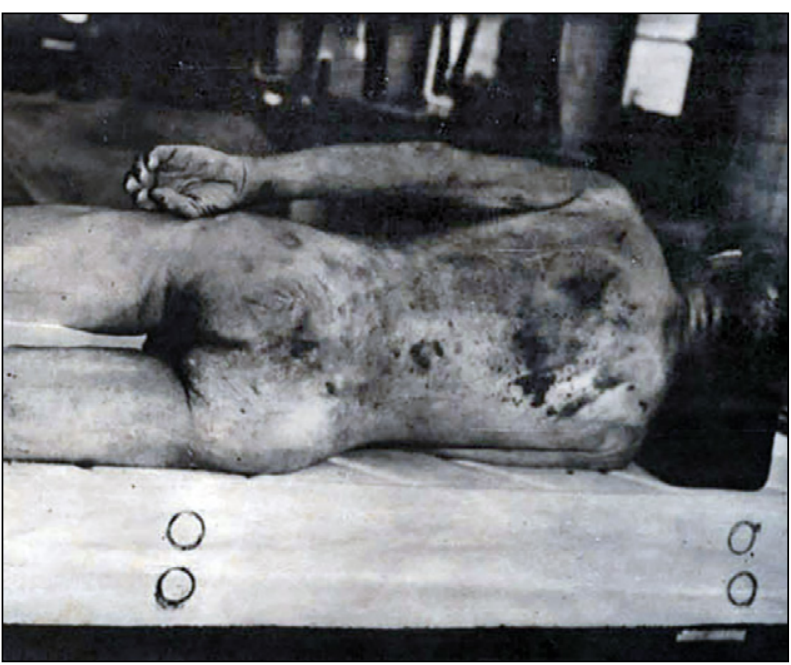

Рисунок 12 - Жертвы анатомических «исследований» А. Хирта, обнаруженные в Анатомическом институте Страсбургского университета после освобождения. Людей убили в газовой камере Начвайлера и доставили в институт на вскрытие. На теле - множественные гематомы. Из материалов «медичинского дела»

(URL: https://nuremberg.law.harvard.edu/ documents/1959-photographs-and-otherrecords?q=Natzweiler\#p.1; дата обращения: 13.06.2021)

провели на заключенных лагеря Нацвайлер (недалеко от Страсбурга).

Их инициатором стал А. Хирт - директор Анатомического института при Рейхсуниверситете Страсбурга. Опыты проходили при участии и поддержке СС-Аненербе, которая в июле 1942 года создала при Страсбургском университете специальный Институт военно-медицинских исследований с отдельным подразделением «Н» (для исследований Хирта). Ранее, зимой 1941-1942 гг., А. Хирт уже пытался изучать профилактические и терапевтические свойства витаминов, в частности, ретинола (витамин А) при поражениях ипритом [33]. При поддержке генерального секретаря СС-Аненербе Вольфрама Зиверса (рисунок 11) А. Хирт заручился согласием на проведение опытов с ипритом лично у Г. Гиммлера. В середине июля 1942 г. рейхсфюрер СС дал А. Хирту разрешение на опыты в Нацвайлере (рисунок 12). В лагере была развернута специальная экспериментальная станция, работой которой руководила СС-Аненербе. Она располагалась в нескольких помещениях, специально выделенных в уже существовавшем в лагере медицинском бараке 26,27 .

После испытаний на крысах, давших положительный результат, перешли к людям. Первый опыт был проведен 25 ноября 1942 г.

риментов. Камера, которая заработала летом 1943 г., находилась за официальной границей лагеря. «Лагерем уничтожения» (Vernichtungslager) типа АушвицаБиркенау Нацвайлер не был. После освобождения Страсбурга в ноябре 1944 г. в лагере обнаружили только 17 тел. Нацвайлер был эвакуирован 31 августа 1944 г. при наступлении союзных войск. В то время в нем находилось около 7,000 заключенных. Операция по эвакуации была завершена 4 сентября. В лагере осталось лишь несколько эсэсовцев. Тем не менее, система продолжала функционировать, поскольку вывезли только главный лагерь, во вспомогательных же по-прежнему оставались люди, которые продолжали работать. Их всех передали в распоряжение администрации концлагеря Дахау в апреле 1945 г. Суд над представителями администрации Нацвайлера состоялся в Вуппертале (Германия, Северный Рейн - Вестфалия) 29 мая 1 июня 1946 г. (Источник The United States Holocaust Memorial Museum. Encyclopedia of Camps and Ghettos, 1933-1945, Volume I: Early Camps, Youth Camps, and Concentration Camps and Subcamps under the SS-Business Administration Main Office (WVHA) Volume Editor Geoffrey P. Megargee, P. 1003-1008. URL: https://www.jstor. org/stable/j.ctt16gzb17.34?seq=1\#metadata_info_tab_contents; дата обращения: 18.04.2021).

${ }^{26}$ Letter to Richard Gluecks concerning the organization of research work at Natzweiler [poison gas]. AUTHOR Wolfram Sievers (administrator of Ahnenerbe Society; Reich Research Council). 11 September 1942. URL: http:// nuremberg.law.harvard.edu/documents/2116-letter-to-richard-gluecks?q=Natzweiler\#p.1 (дата обращения: 13.06.2021).

27 Сохранился любопытный документ - письмо В. Зиверса в секретариат Г. Гиммлера от 3 ноября 1942 г., содержащий в себе следы административно-финансовой «перебранки», связанной с опытами с ипритом в Нацвайлере. А. Хирт нажаловался своему начальству, что лагерная администрация неохотно идет навстречу его пожеланиям и чинит препятствия. Кроме того, там потребовали дополнительной оплаты за содержание заключенных, которых задействовали в опытах. Дело в том, что «для чистоты эксперимента» предполагалось, что заключенных должны были кормить не обычной лагерной пищей, а рационом охранников. В результате - расходы на дополнительное питание 10 человек, а опыты могли продолжаться до 10 месяцев, т.е. расходы должны были составить порядка 4000 рейхсмарок. В. Зиверс в докладе наверх возмущался «шкурническим» подходом лагерной администрации: «Кажется, эта публика в Нацвайлере пытается выжать из этого бизнеса как можно больше денег». Одновременно он поставил в пример администрацию Дахау, которая, по его словам, всегда «с пониманием» относилась к их изысканиям и «никогда не заикалась об оплате за заключенных». Тут же выяснился и финансовый вопрос. Работу Института военно-научных исследований финансировала Ваффен-CC. (URL: http://nuremberg.law.harvard.edu/documents/1077-memorandum-torudolf-brandt?q=Natzweiler\#p.1; дата обращения: 13.06.2021). К слову сказать, вопрос о дополнительном питании и чистоте экспериментов, очевидно, так и не был решен удовлетворительно, поскольку в своих отчетах А. Хирт оговаривал, что «подопытные» истощены. 
на 15 заключенных ${ }^{28}$. Но предоставленный Ваффен-СС иприт оказался настолько некачественным, что опыт был признан неудачным. В начале декабря 1942 г. А. Хирт продолжил эксперименты с целью проверить «защитные свойства» витаминов А, группы В и С при ипритных поражениях [34]. Результаты дали картину, обратную ожидаемой - оказалось, что, в отличие от крыс, применительно к людям витамин А не только не обеспечивал защиту, но наоборот, дал гиперчувствительность к иприту.

В конце 1943 г. В. Зиверс и А. Хирт уже рассматривали возможность расширения экспериментов с ипритом и витаминами в Нацвайлере, а также в Дахау. Сначала предполагалось поставить опыты на крысах с участием 1000 животных, а потом проверить «терапевтические свойства» витамина А на 240 заключенных.

Впоследствии бывший заключенный Нацвайлера голландец Герит Хендрик Налес (Gerit Hendrik Nales), находившийся в лагере с ноября 1942 г., рассказал на нюрнбергском трибунале по «делу врачей», что в период с апреля по май 1943 г. в лагере действительно ставили опыты над 15 заключенными немцами. Им на кожу наносили некое «вещество», вызывавшее «ужасные раны», которые потом распространялись по всему телу, которое также вызывало слепоту (очевидное описание поражения ипритом). По его словам, как минимум трое «подопытных» в течение нескольких дней скончались в ужасных мучениях.

В итоге в 1944 г. А. Хирт представил итоговый отчет о результатах своих экспериментов. В нем нигде не говорилось, что опыты ставились на заключенных. Зато там было сказано, что, возможно, результат будет лучше в случае перорального приема мультивитаминов (А, С и группы В), а также в случае инъекций витамина В1 с глюкозой.

Согласно показаниям личного секретаря-референта Г. Гиммлера Рудольфа Брандта (нем. - Rudolf («Rudi») Emil Hermann Brandt, 1909-1948) на трибунале по «медицинскому делу», опыты с ипритом в Нацвайлере и Заксенхаузене продолжались до 1944 г. включительно ${ }^{29}$.

Концентрационньй лагерь Нацвайлер. Опьты с фосгеном Отто Бикенбаха. 17 марта 1943 г. Институт военно-медицинских исследований проводил научно-практическую конференцию, куда был приглашен, в частности, доктор Отто Бикенбах (нем. - Otto
Bickenbach, 1901-1971) с медицинского факультета Страсбургского рейхсуниверситета [33]. С 1939 г. он работал над проблемой лечения легочных поражений фосгеном. В феврале 1940 г. он приступил к экспериментам, направленным на изучение профилактических и терапевтических свойств гексаметилентетрамина (уротропина). Немцам было известно, что уротропин в Первую мировую войну использовался в русской армии для пропитки противогазовых повязок для защиты от хлора и фосгена во время газобаллонных атак. Его действие хотели проверить (рисунок 13).

Программа исследований О. Бикенбаха предполагала серию испытаний на животных (кошки и обезьяны), а также эксперименты на себе. По его данным, опыты на животных показали высокую эффективность уротропина. На конференции, проводившейся под эгидой СС-Аненербе, был показан отснятый им в 1940 году документальный фильм об опытах с уротропином на кошках и обезьянах.

После конференции В. Зиверс предложил О. Бикенбаху продолжить опыты «во взаимодействии» с А. Хиртом в Нацвайлере. О. Бикенбах согласился, поскольку это означало получение доступа к «биоматериалу».

Сведения о первой серии опытов крайне противоречивы. Известно, что к началу апреля 1943 г. в Нацвайлере соорудили газовую камеру объемом $20 \mathrm{~m}^{3}$ специально для опытов О. Бикенбаха с фосгеном. Известно, что в том же апреле А. Хирт сообщил О. Бикенбаху, что он может начинать.

О дальнейшем известно лишь по послевоенным показаниям единственного свидетеля Фердинанда Холла, который был в лагере капо (полицейским). Он сообщил, что первая серия опытов состоялась в июне 1943 г. При этом он путался в показаниях относительно количества заключенных, на которых ставили опыты (от 90 до 150), а также количества погибших (50-60 человек). Поэтому этот эпизод до сих пор считается среди специалистов не до конца выясненным - вплоть до того, был ли он вообще.

Следующая серия опытов с фосгеном была проведена в Нацвайлере в июне и августе 1944 г. Соисполнителем был ассистент О. Бикенбаха Гельмут Рюль (нем. - Helmut Rühl, 1918-после 1980). Определенную техническую помощь оказал В. Вирт, хотя не известно, в какой мере он был осведомлен о проходящем в Нацвайлере, по-

\footnotetext{
${ }_{28}$ В некоторых источниках имеются обрывочные сведения об опытах А. Хирта с ипритом в октябре 1942 г. Эксперименты ставились на 150 заключенных, которым предварительно в течение двух недель давали усиленное питание. Затем им наносили иприт на кожу и заставляли дышать парами ОВ. По меньшей мере 50 человек погибли, остальные получили поражения и были убиты позднее, в газовых камерах [35].

${ }^{29}$ Rudolf Emil H. Brandt (SS Obersturmbannfuehrer (Himmler's personal staff). Affidavit concerning the poison gas experiments at Sachsenhausen and Natzweiler. 14 October 1946. URL: http://nuremberg.law.harvard.edu/ documents/1686-affidavit-concerning-the-poison?q=Natzweiler\#p.1 (дата обращения: 13.06.2021).
} 


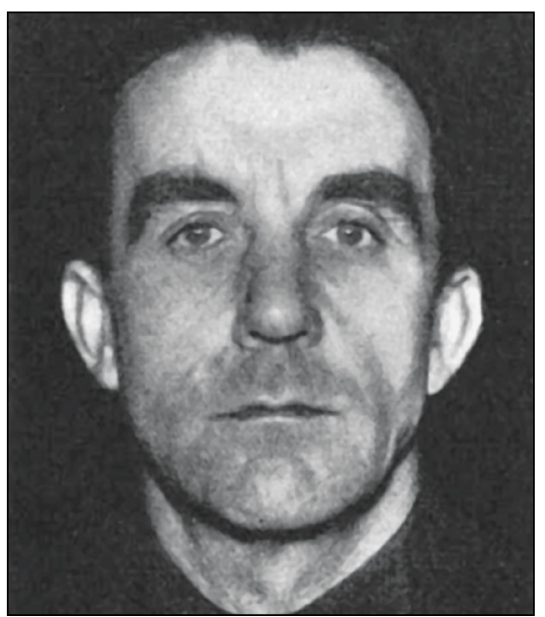

Рисунок 13 - Отто Бикенбах [31]

скольку Институт фармакологии просили всего лишь помочь откалибровать измерительную аппаратуру.

Опыты в газовой камере Нацвайлера проходили с 15 июня по 8 августа 1944 г. В них участвовали 40 заключенных. 20 давали уротропин перорально, 20 - сделали инъекции. Контрольная группа из 8 заключенных находилась в газовой камере без защиты. Большую часть заключенных (кроме нескольких немцев) составляли цыгане, которых специально доставили из «цыганского лагеря» в Аушвице-Биркенау. Заключенных заводили в камеру по четыре человека. Концентрацию фосгена постепенно увеличивали, а дозировку уротропина, наоборот, понижали. Выживший участник опыта Вилли Херцберг (Willy Herzberg) после войны давал показания о том, что О. Бикенбах лично заводил заключенных в газовую камеру, разбивал емкости с фосгеном и быстро выходил, после чего двери герметизировались.

Согласно заключительному отчету О. Бикенбаха рейхскомиссару здравоохранения и санитарии Карлу Брандту (нем. - Karl Franz Friedrich Brandt, 1904-1948), 14 человек скончались. Под конец опыта концентрация фосгена в камере значительно превышала считавшуюся летальной.

О. Бикенбах фактически подтвердил защитные свойства уротропина. Для этого ему пришлось ставить эксперименты, где смерть «подопытного» человека была частью методики - одной из задач было установить, при каких дозировках уротропина и какой концентрации фосгена смерть будет неизбежной.

Кониентрационный тагерь Нойенгамме ${ }^{30}$. Последние известные испытания на заключен- ных происходили в период между декабрем 1944 г. и мартом 1945 г. в Нойенгамме (на территории Гамбурга). Их инициатором стал профессор Карл Людвиг Вернер Хаазе (нем. - Karl Ludwig Werner Haase, 1903-1980) из рейхсинститута гигиены воды, почвы и воздуха (рисунок 14).

После разрушения плотины «Möhne Reservoir» британскими ВВС в мае 1943 г. К. Хаазе был введен в состав рабочей группы, занимавшейся ее восстановлением. Он высказал предположение, что британские ВВС могли заразить воду боевыми ОВ. Ему было поручено в лабораторных условиях разработать новый метод очистки воды от ОВ.

Весной 1944 г. К. Хаазе предложил обеззараживать отравленную люизитом воду хлорноватистой кислотой. Военные опробовали этот способ в Раубкаммере. Испытания провели также в Военно-медицинской академии, причем однозначных результатов не получилось. Тем временем К. Хаазе приступил к разработке специального аппарата для очистки воды хлорноватистой кислотой. Альтернативный способ - использование активированного угля в качестве сорбента - он отвергал на том основании, что количества угля, достаточного для обеззараживания такого количества воды, в доступе просто нет.

О его предложениях были поставлены в известность, в частности, имперский руководитель здравоохранения обергруппенфюрер СС Леонардо Конти (нем. - Leonardo Konti, 19001945) и лично Г. Гиммлер, который одобрил продолжение исследований в концлагере. Для этих целей был выбран лагерь Нойенгамме.

К. Хаазе готовил эксперименты с июня 1944 г. Аппарат планировалось установить в Нойенгамме к концу июля. 5 августа и 1 сентября 1944 г. он посетил Нойенгамме. В один из этих дней хлорноватистая кислота была залита в источник питьевой воды, откуда брали воду для приблизительно 10,000 заключенных. Целью опыта была проверка действия на человеческий организм самой кислоты. Согласно отчетам К. Хаазе, ни о каких явных проблемах со здоровьем у заключенных, которые употребляли воду с кислотой, не наблюдалось.

10 октября 1944 г. К. Хаазе продолжил испытания вместе с В. Виртом на испытательном полигоне в Раубкаммере.

В период с 3 по 15 декабря 1944 г. около 150 заключенных лагеря подверглись эксперименту с питьевой водой с люизитом, которую пропустили через изобретенные К. Хаазе очистные сооружения с хлорноватистой кисло-

\footnotetext{
${ }^{30}$ Изначально возник как филиал Заксенхаузена, в 1940 г. преобразован в отдельный лагерь. Расширение системы концлагерей обусловливалось растущими потребностями экономики Германии, а также сохранением планов А. Гитлера по перестройке немецких городов. Гросс-Розен и Нацвайлер, дополнившие Нойенгамме, Маутхаузен и Флоссенбург, должны были обеспечивать экономику строительными материалами [32].
} 
той. Начинали с минимальной концентрации люизита, потом ее постепенно увеличивали до концентраций, которые «примерно в сто раз» превышали предельно допустимые (по оценкам Военно-медицинской академии). Если верить отчетам К. Хаазе, лагерные врачи из СС никакого ухудшения состояния здоровья подопытных не зафиксировали.

К. Хаазе предполагал в январе 1945 г. продолжить эксперименты с целью изучения действия на человеческий организм длительного употребления такой «очищенной» воды, поскольку предполагалось, что в воде все равно остается определенное количество мышьяка. Г. Гиммлер разрешения не дал.

Тем не менее К. Хаазе настоял на проведении опытов с азотистыми ипритами на том основании, что их химический состав отличается от люизита. В январе - начале февраля 1945 г. в Нойенгамме провели серию опытов с азотистыми ипритами и доложили о «также положительных результатах».

Далее нацистские ученые предложили продолжить эксперименты с целью уточнения летальных токсодоз сразу нескольких ОВ. Предлагалось использовать заключенных, приговоренных к смертной казни. По предложенным им методикам опыты предполагалось продолжать до смерти участников экспериментов.

Г. Гиммлер опыты запретил. 16 февраля 1945 г. он отозвал свое разрешение на эксперименты в Нацвайлере «по соображениям текущей политической ситуации». Это был первый известный

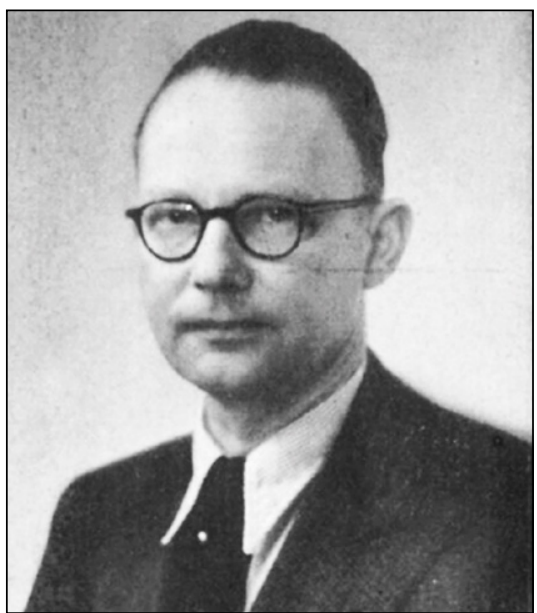

Рисунок 14 - Людвиг Вернер Хаазе [31]

случай, когда Г. Гиммлер отказался санкционировать какие бы то ни было опыты на людях в концлагере. Война подходила к концу.

Расплата. После окончания войны пришло время отвечать за содеянное [36-38]. 20 ноября 1945 г. во Дворце юстиции Нюрнберга открылся Международный военный трибунал (МВТ) - первый и главный судебный процесс по обвинению бывших руководителей Германии в преступлениях против мира, против человечности ${ }^{31}$, нарушениях законов войны и в заговоре с целью совершения данных преступных действий [39]. Трибунал завершил работу 1 октября 1946 г. и вынес обвинительные приговоры главным руководителям Третьего рейха.

\footnotetext{
31 Зарождение понятия преступления против человечности связано с деятельностью российского юриста-международника Ф.Ф. Мартенса (1845-1909), принимавшего участие в разработке Конвенций о законах и обычаях сухопутной войны 1899 г. и 1907 г. Далее его связывают с совместной декларацией стран Антанты Османской империи в 1915 г. [37]. Впоследствии они были сформулированы в Ст. 6 Устава МВТ:

«Трибунал, учрежденный Соглашением, упомянутым в статье 1 настоящего Устава для суда и наказания главных военных преступников европейских стран оси, имеет право судить и наказывать лии, которые, действуя в интересах европейских стран оси индивидуально или в качестве членов организачии, совериили любое из следующих преступлений.

Следующие действия или любые из них являются преступлениями, подлежащими юрисдикиии Трибунала и влекущими за собой индивидуальную ответственность:

а) преступления против мира, а именно: планирование, подготовка, развязывание или ведение агрессивной войны или войны в нарушение международных договоров, соглашений или заверений, или участие в общем плане или заговоре, направленных к осуществлению любого из вышеизложенных действий;

b) военные преступления, а именно: нарушения законов или обычаев войны. К этим нарушениям относятся убийства, истязания или увод в рабство или для других иелей гражданского населения оккупированной территории; убийства или истязания военнопленных или лии, находящихся в море; убийства заложников; ограбление общественной или частной собственности; бессмысленное разрушение городов или деревень; разорение, не оправданное военной необходимостью, и другие преступления;

c) преступления против человечности, а именно: убийства, истребление, порабощение, ссылка и другие жестокости, совершенные в отношении гражданского населения до или во время войны, или преследования по политическим, расовым или религиозным мотивам в иееля осуществления или в связи с любым преступлением, подлежащим юрисдикиии Трибунала, независимо от того, являлись ли эти действия нарушением внутреннего права страны, где они были совершень, или нет.

Руководители, организаторы, подстрекатели и пособники, участвовавшие в составлении или в осуществлении общего плана или заговора, направленного к совершению любых из вышеупомянутых преступлений, несут ответственность за все действия, совершенные любыми лииами в иелях осуществления такого плана» (URL; https://docs.cntd.ru/document/901737883).
} 


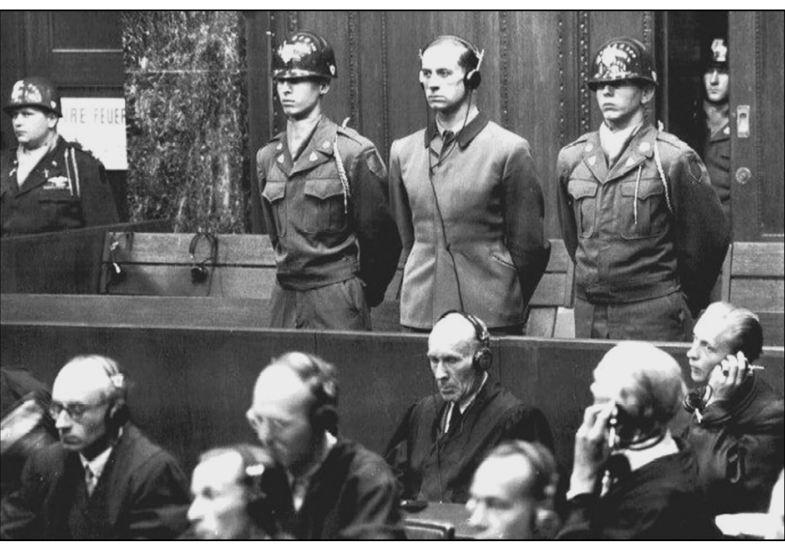

Рисунок 15 - Судебный процесс «Соединенные Штаты Америки против Карла Брандта и дp». (URL: https://commons.wikimedia.org/wiki/ File:Karl-Brandt.jpg; дата обращения: 13.06.2021)

На МВТ неоднократно звучали обвинения в адрес немецких врачей в проведении недобровольных испытаний на заключенных концентрационных лагерей тех или иных химических веществ и биологических средств [39]. В частности, было показано, что в Аушвице-Биркенау «производилось изучение действия разных химических препаратов по заказам немецких фирм... В тагере производились также опыты над мужчинами для установления действия раздражающих химических веществ на кожуголени с иелью искусственно вызывать язвы и флегмо- ны. Производился и ряд других опытов, таких, как искусственно заражение малярией, искусственное оплодотворение и т.д.». Упоминалось об опытах в Бухенвальде с искусственным заражением малярией и сыпным тифом с целью проверки эффективности различных вакцин, в том числе произведенных в лагере, об опытах с ожогами фосфором для поиска средств лечения ожогов и т.д. В. Зиверс дал показания об опытах А. Хирта с ипритом в Нацвайлере с целью поиска и апробации методов лечения поражений. Опыты проводились по личному распоряжению рейхсфюрера СС Г. Гиммлера ${ }^{32}$ как минимум до начала марта 1944 г. Однако на МВТ эти сюжеты звучали как проходные на фоне других медицинских преступлений и тем более газовых камер $[39,40]$ в «лагерях уничтожения».

«Медицинское дело». Союзным Контрольным советом 3320 декабря 1945 г. был принят Закон № 10, который уполномочил союзные державы арестовывать «военных и других подобных преступников, за исключением тии, против которых ведется преследование Международным Военным Трибуналом», и постановил учредить трибуналы для суда над ними. Задача судебного преследования таких лиц ложилась на каждую из оккупационных держав (рисунок 15).

Согласно п. 1 (b, c) ст. II Закона № 10, в качестве военных преступлений квалифицировались «жестокости или враждебные действия против лии, или имущества, представляющие

\begin{abstract}
Ныне действующее определение преступлений против человечности дано в Римском статуте Международного уголовного суда (вступил в силу 1 июля 2002 г.).

32 Очевидно, штандартенфюрер СС В. Зиверс, проходивший в данном случае как свидетель, очень не хотел перейти в разряд обвиняемых. В своих показаниях он настаивал на том, что «Пробессор Хирт разработал метод лечения ран, вызванных действием отравляющего вещества «Лост». При создании метода лечения он в порядке эксперимента проводил опыты на самом себе, которые привели к тяжельм последствиям для его здоровья... Гиммлер интересовался этими опьтами, и он очень разволновался, когда усльшил, что Хирт проводит эксперименты на самом себе. Гиммлер сослался при этом на распоряжение бюрера, чтобы для таких опьтов использовались добровольцы из числа заключенных или из числа приговоренных к смертной казни преступников. Только после требования Гиммлера Хирт провел контрольные опьты на 20 заключенных, но сделал он это только тогда, когда уже было известно на основании опьтов, проведенных на самом себе, что вредные последствия, вызываемые этими экспериментами, не носят длительного характера. Он указал далее на то, что гораздо важнее (это был первый рабочий контакт с Хиртом) получить для этих экспериментов достаточное количество животных, так как с начала войны их количество сократилось настолько, что уже невозможно было проводить необходимые научные опыты»... «после опытов на самом себе он провел эти эксперименты на 20 заключенных, которые добровольно предоставили себя в его распоряжение». Свою собственную роль в этих экспериментах он сводил к роли «лишь почтальона» и во время дачи показаний регулярно страдал забывчивостью. Эта тактика не сработала, его все равно осудили на другом трибунале и повесили в 1948 г.
\end{abstract}

${ }_{33}$ Орган верховной власти в оккупированной Германии, образованный после Второй мировой войны державами-победительницами. В соответствии с контрольным механизмом, установленным соответствующим соглашением от 14 ноября 1944 г. и подтвержденным на Потсдамской конференции летом 1945 года, верховная власть в Германии осуществляется главнокомандующими вооруженных сил четырех держав-победительниц «каждым в своей зоне оккупации, по инструкциям от своих соответствующих Правительств, а также совместно, по вопросам, затрагивающим Германию в целом». Соответственно в Контрольный совет входили маршал Г.К. Жуков, генерал Дуайт Эйзенхауэр, фельдмаршал Бернард Монтгомери и генерал Латр де Тассиньи. Учредительное заседание Контрольного совета состоялось 30 июля 1945 г. одновременно с проходившей Потсдамской конференцией. Последнее заседание состоялось 20 марта 1948 года. Формально совет был ликвидирован только с объединением Германии после обретения Германией полного суверенитета в соответствии с положениями Договора «Два плюс четыре» 1990 года. 
Разработка и испытания на людях боевых отравляющих веществ и средств лечения поражений в Германии...

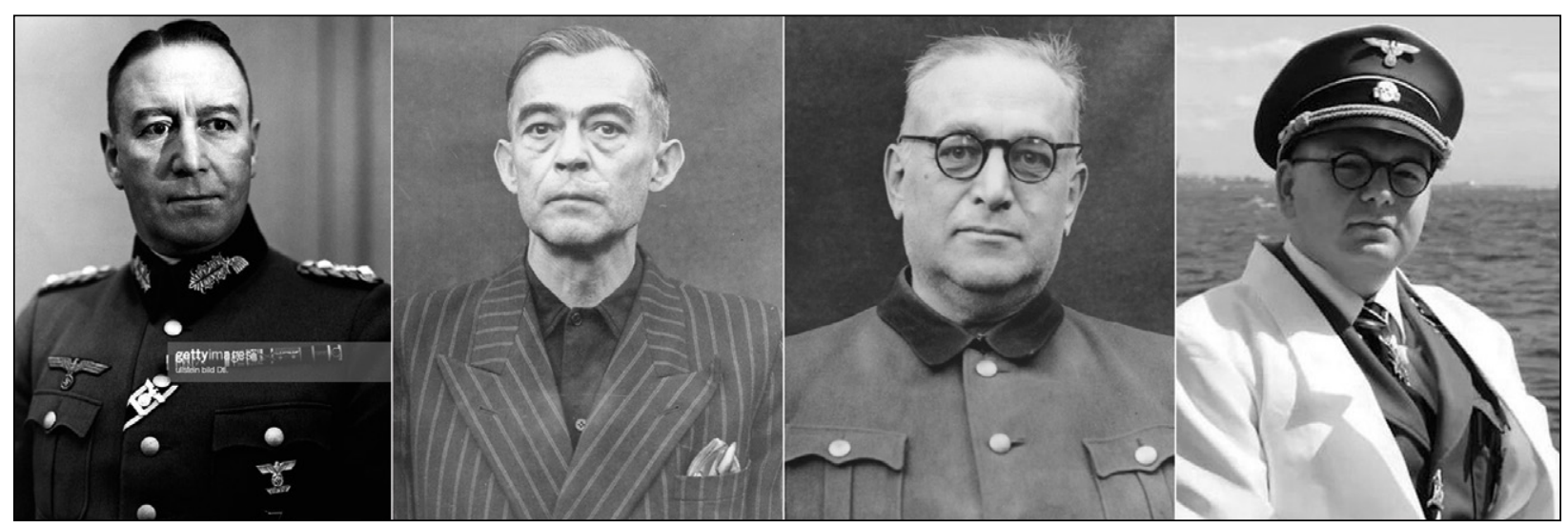

Рисунок 16 - Подсудимые на прочессе «Соединенные Штаты Америки против Карла Брандта и др.» (слева на право): Зигфрид Хандлозер - приговорен к пожизненному заключению; Курт Бломе, Пауль Росток - длительные сроки заключения. Карл Гебхардт - казнен за военные преступления и преступления против человечности)

нарушение законов или обычаев войны, включая, но не ограничиваясь: убийство, плохое обращение или увод в рабство или для каких-либо других иелей гражданского населения из оккупированной территории, убийство или плохое обращение с военнопленными или находящимися в море, убийство заложников, ограбление общественной или частной собственности, умышленное разрушение городов, населенных пунктов или деревень или опустотение, не оправданное военной необходимостью».

К преступлениям против человечности относились «жестокости и враждебнье действия, включая, но не ограничиваясь: убийство, истребление, обращение в рабство, депортация, заключение в тюрьму, пьтки, изнасилование или другие бесчеловечные действия, совериаемье против любого гражданского населения, или преследования на политической, расовой или религиозной почве, вне зависимости от того, были ли эти преступления совершены в нарушение законов страны или нет» [41].

На основании этого закона ${ }^{34}$ было проведено несколько процессов, которые союзники организовывали сами, каждый в своей оккупационной зоне. В одном только Нюрнберге с 1946 по 1949 г. состоялось 12 трибуналов.

Первым стал процесс «Соединенные Штаты Америки против Карла Брандта и др.» (Дело № 1) или «дело врачей» («медицинское дело»), который проходил в Нюрнберге с 9 декабря 1946 г. по 20 августа 1947 г. ${ }^{35}$ [42]. Нюрнберг входил в оккупационную зону США, поэтому процесс организовали США ${ }^{36}$. Все судьи были из США. Сторона обвинения была представлена американскими юристами, сторона защиты - немецкими. Суду были преданы руководители медицины Германии за организацию и проведение экспериментов на людях. В их числе - начальники медицинских служб Вермахта, Люфтваффе, Ваффен-СС и гражданской медицины, всего 23 человека, из них 20 врачей, один юрист и два чиновника.

На скамье подсудимых оказались, в частности: К. Брандт - личный врач А. Гитлера, группенфюрер СС и генерал-лейтенант Ваффен-СС, рейхскомиссар по здравоохранению и санитарии, член Совета исследований Рейха; Зигфрид Хандлозер (нем. - Siegfried Handloser, 1885-1954) - генерал-лейтенант медицинской службы, медицинский инспектор Сухопутных войск, начальник медицинской службы Вермахта; Курт Бломе (нем. - Kurt Blome, 18941969) - заместитель Имперского руководителя здравоохранения, уполномоченный по онкологическим исследованиям Совета исследований Рейха; Пауль Росток (нем. - Paul Rostock, 1892-1956) - главный хирург Хирургической клиники в Берлине, хирургический советник армии, начальник Управления медицинской науки и исследований; Карл Гебхардт (нем. - Karl Franz Gebhardt, 1897-1948) - группенфюрер CC и генерал-лейтенант Ваффен-СС, личный врач рейхсфюрера СС Г. Гиммлера, главный хирург штаба главного врача СС и полиции, президент Красного Креста Германии; Р. Брандт (нем. Rudolf («Rudi») Emil Hermann Brandt, 1909-1948) - штандартенфюрер (полковник) в общих СС,

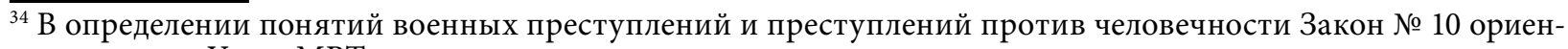
тировался на Устав МВТ.

${ }^{35}$ Большая часть материалов по процессу была сразу же засекречена. Изданный в США официальный отчет содержит многочисленные лакуны.

36 Французы проводили аналогичные военные трибуналы в Лионе и Меце. 
личный помощник (референт) рейхсфюрера СС Г. Гиммлера, министерский советник и начальник управления делами министерства внутренних дел Рейха; В. Зиверс - штандартенфюрер CC, управляющий делами общества Аненербе и директор Института военно-научных исследований, заместитель председателя управляющего совета директоров Совета исследований Рейха (рисунок 16).

Обвинения в испытаниях боевых отравляющих веществ на людях были предъявлены:

«D) Опыты с ипритом (Lost) (горчичный газ). В разное время между сентябрем 1939 и апрелем 1945 проводились опыты в концентрачионных тагерях Заксенхаузен, Нацвайлер и других концентрационных тагерях в интересах германских вооруженных сил с иелью изучения наиболее эф фективных способов течения поражений, нанесенных ипритом. Иприт - это отравляющий газ, который обычно известен как горчичный газ. Поражения ипритом наносились подопытным преднамеренно. Некоторые из подопытных погибли в результате этих экспериментов, другие испьтывали сильную боль и получили увечья. Подсудимые Карл Брандт, Хандлозер, Бломе, Росток, Гебхардт, Рудольф Брандт и Зиверс несут особую ответственность и обвиняются в участии в данных преступлениях».

Всем 23 подсудимым были предъявлены обвинения и в других медицинских преступлениях в концлагерях Дахау, Равенсбрюк, Аушвиц-Биркенау, Бухенвальд и др. Часть экспериментов (высотные, по обморожению, с морской водой, с зажигательными бомбами и т.д.) проводилась в интересах Вермахта, Люфтваффе и Кригсмарине. Часть направлена на поиск средств профилактики и лечения опасных, особо опасных, а также широко распространенных заболеваний (малярии, тифа, газовой гангрены, столбняка, туберкулеза и т.д.) и на проверку эффективности вакцин ${ }^{37}$. И наконец, часть была направлена на решение особо актуальных в то время задач расового характера (эксперименты по стерилизации с прицелом на массовость, по эвтаназии неизлечимо больных, психиатрических больных и т.д.). Отдельным пунктом обвинения фигурировала коллекция «еврейских скелетов» А. Хирта.

Приговор, не подлежавший обжалованию, был вынесен 20 августа 1947 г. Семь человек, в числе которых К. Брандт, Р. Брандт, К. Гебхардт и В. Зиверс, приговорены к смертной казни через повешение, приговор приведен в исполнение 2 июня 1948 г. в тюрьме для во- енных преступников в Ландсберге (Бавария). Пятерых, в том числе 3. Хандлозера, приговорили к пожизненному заключению. Он отсидел шесть лет. Освобожден досрочно в декабре 1953 г. в связи с резким ухудшением здоровья, умер от рака 3 июля 1954 г. в Мюнхене. Четверо получили различные сроки тюремного заключения.

В их числе был оберфюрер СС Гельмут Поппендик (нем. - Helmut Poppendick, 19021994), причастный к экспериментам в Нойенгамме. Он был приговорен к 10 годам тюрьмы, освобожден 1 февраля 1951 г., после чего продолжил врачебную деятельность в Ольденбурге, где и скончался 11 января 1994 г. Семерых подсудимых, в числе которых П. Росток и К. Бломе, оправдали. Оба продолжили заниматься медицинской практикой. П. Росток умер 17 июня 1956 г., К. Бломе - 10 октября 1969 г.

А. Хирта судил позднее и заочно французский военный трибунал во время первого из двух судебных процессов (Struthof Medical Trials) по преступлениям в Нацвайлере (1952 г. - трибунал в Меце, 1954 г. - трибунал в Лионе). Главным пунктом обвинения стала коллекция «еврейских скелетов», для комплектования которой людей убивали специально, а также опыты на людях [43].

Заключение. Еще в конце XIX - начале XX в. именно Германия (Пруссия) стала первой европейской страной, где на уровне законодательной, исполнительной и судебной ветвей власти стали запрещать медицинские опыты на людях без их согласия и требовать обязательного информированного добровольного согласия пациента на медицинское вмешательство.

Первым таким документом стало распоряжение министерства внутренних дел Пруссии от 1891 г. об использовании изобретенного в 1890 г. Робертом Кохом (нем. - Heinrich Hermann Robert Koch, 1843-1910) препарата - туберкулина при лечении заключенных. В распоряжении указывалось, что он может быть использован только в тех тюрьмах, при которых существуют больницы или другие медицинские учреждения, а также только в тех случаях, если врач, использующий туберкулин, в этой же клинике сам и живет - чтобы иметь возможность отслеживать пациентов и вмешаться в любой момент. Кроме того, этот препарат «ни при каких условиях не должен использоваться против воли пациента». Правда, это распоряжение касалось только заключенных и не распространялось на всех остальных - не в последнюю

\footnotetext{
$\overline{37}$ Такие цели исследований были бы вполне нормальными, если бы не ряд весьма существенных обстоятельств. Для этих экспериментов здоровых людей заражали специально. Кроме того, методики проведения некоторых опытов, направленных, в частности, на определение токсичности тех или иных химикатов, предполагали их продолжение вплоть до смерти «подопытных». Некоторые были признаны бессмысленными и «причиняющими излишние страдания».
} 
очередь по причине распространенности этого заболевания.

Следующим эпизодом стало так называемое «дело Нейссера» [44]. Альберт Нейссер (нем. - Albert Neisser, 1855-1916) (рис. 35), opдинарный профессор дерматологии и венерологии, директор Дерматологической клиники в Бреслау, в истории медицины известный как первооткрыватель гонококка - возбудителя гонореи, проводил исследования, направленные на поиск средств профилактики и лечения сифилиса. В 1892 г. он ввел восьми госпитализированным малолетним девицам изобретенную им сыворотку, полученную от больных пациентов, чтобы проверить ее способность «убивать сифилитический яд». Четверо из них были проститутками, госпитализированными с венерическими заболеваниями (но не сифилисом), еще четверо - с различными кожными заболеваниями. О том, что на них ставятся опыты, девицы в известность поставлены не были. В течение ближайших четырех лет некоторые из них заболели. А. Нейссер пришел к выводу, что вакцинация «не сработала», однако объяснял это обстоятельство не неэффективностью сыворотки, а «естественными обстоятельствами», т.е. нахождением в группе риска по сифилису в силу занятий проституцией.

Результаты своих исследований А. Нейссер в 1898 г. опубликовал в специализированном научном журнале. Однако в 1900 г. мюнхенская либеральная газета «Freie Presse» («Свободная пресса») опубликовала пространную статью «Arme Leute in Krankenhausen» («Бедные люди в больницах»), в которой ее автор, в частности, обвинил А. Нейссера в опытах на несовершеннолетних, да еще и без их согласия.

Последовали разбирательство, суд и дисциплинарное расследование. «Камнем преткновения» стал вопрос о том, давали ли испытуемые/пациенты согласие на лечение, носившее, по сути, экспериментальный характер. А. Нейссер вины не признавал и упирал на то, что в данном случае оно и не требовалось, поскольку, во-первых, этого требовали интересы науки, а во-вторых, пациентки в силу низкого образовательного и культурного уровня все равно ничего бы не поняли. Медицинское сообщество А. Нейссера поддержало ${ }^{38}$. Позиция юристов того времени сводилась к тому, что «нетерапевтические», то есть экспериментальные исследования, без согласия испытуемых соответствуют критериям понятия причинения физического ущерба в уголовном праве. Научные цели экспериментов смягчающими обстоятельствами считаться были не должны.

В итоге А. Нейссер был признан виновным «в нарушении долга врача» $[44,45]$. Королевский дисциплинарный суд (Königlicher Disciplinarhof für nichtrichterliche Beamte) приговорил его к штрафу в размере 300 рейхсмарок. Также он должен был возместить судебные издержки в сумме 1245 марок (в то время годовой доход А. Нейссера составлял 2400 марок) [46].

Общественный резонанс, который вызвало «дело Нейссера», привел к тому, что оно несколько раз обсуждалось в парламенте Пруссии, который обратился к правительству с предложением принять меры.

После собственного разбирательства 29 декабря 1900 г. министерство по делам религии, образования и медицины обнародовало положение, которое распространялось на все лечебные учреждения Пруссии. Оно обязывало врачей при любых экспериментах («нетерапевтическом вмешательстве») обязательно получать информированное добровольное согласие пациентов и ставить их в известность относительно возможных негативных последствий ${ }^{39}$.

Таким образом, в годы Второй мировой войны врачи из СС действовали вопреки законам, научным и гуманистическим традициям в первую очередь своей собственной страны. И, несмотря на законность и естественность целей и задач этих опытов, именно бесчеловечность

\footnotetext{
${ }_{38}$ В конце XIX в. экспериментальные исследования, в первую очередь в только что зарождающейся области бактериологии, иммунологии и физиологии, проводились главным образом в больницах на пациентах, причем, как правило, действительно без их согласия, поскольку «интересы науки и прогресса» представлялись более важными.

${ }^{39}$ Полный текст документа:

«Рейхсминистр Пруссии по делам религии, образования и медицины

Указ всем медицинским начальникам (директорам) университетских больнии, поликлиник и других лечебных учреждений

І. Приказываю медицинским начальникам (директорам) университетских больнии, поликлиник и всех остальных лечебных учреждений - любое медицинское вмешательство с иелями, отличными от диагностических, лечебных, а также иммунизации, вне зависимости от других правовых или моральных обоснований, исключается при любых обстоятельствах, если:

(1) Испьтуемый человек несовершеннолетний или недееспособный в силу иных причин;

(2) Испытуемый человек не давал своего недвусмысленного согласия;

(3) Согласию не предшествовало разбяснение должным образом возможных негативных последствий вмешательства.

II. В то же время постановляю, что:
} 
их методов являлась грубейшим нарушением научной и медицинской этики, а также носила преступный характер, что и было подтверждено соответствующими обвинительными заключениями.

По итогам процесса 1947 г. был составлен Нюрнбергский кодекс - первый международный документ, вводивший этические нормы для ученых, занимающихся экспериментами на людях [47-50]. Он включал в себя 10 принципов, главный из которых сводился к тому, что для проведения эксперимента на человеке необходимо его добровольное осознанное согласие после предоставления ему полной информации о характере, продолжительности и цели проводимого эксперимента; о методах и способах его проведения; обо всех предполагаемых неудобствах и опасностях, связанных с проведением эксперимента, и, наконец, возможных последствиях для физического или психического здоровья испытуемого, могущих возникнуть в результате его участия в эксперименте.

Кроме того, Нюрнбергским кодексом предписывалось избегать всех излишних физических и психических страданий и повреждений. Также предполагалось, что ни один эксперимент не должен проводиться в случае, если есть основания предполагать возможность смерти или инвалидизирующего ранения испытуемого. Эксперимент должен быть прекращен в случае, если его продолжение может привести к ранению, инвалидности или смерти испытуемого.

Принципы, сформулированные в Нюрнбергском кодексе, стали основой для многих международных ${ }^{40}$ и национальных, в том числе российских, законодательных актов в области проведения медицинских исследований на человеке.

(1) Такого рода вмешательство может проводиться только медицинским начальником (директором) лично или по его специальному разрешению;

(2) Во всех случаях таких вмешательств выполнение требований I (1-3) и II (1), а также прочие обстоятельства документируются в медииинской карте.

III. Существующие инструкиии относительно медицинского вмещательства с диагностическими и лечебными целями, а также иелями иммунизации, настоящим указом не затрагиваются.

Берлин, 29 декабря 1900

Министр по делам религии и т.д.

Umyдm»*

* Генрих Конрад фон Штудт (нем. - Heinrich Conrad von Studt, 1838-1921) - прусский юрист и политический деятель, с 1899 г. - министр по делам религии, образования и медицины (Ministerium der Geistlichen, Unterrichts und Medizinal-Angelegenheiten)

${ }^{40}$ Нюрнбергский кодекс послужил фундаментом принятых в течение XX века важнейших международных этических и правовых актов в области биомедицинских исследований с участием человека в качестве субъекта. Следующим шагом в области проведения экспериментов на людях явилась Хельсинкская декларация, которая была принята на восемнадцатой Генеральной Ассамблее Всемирной Медицинской Ассоциации в Хельсинки (Финляндия) в июне 1964 года. Текст Декларации см. [51].

\section{БЛАГОДАРНОСТИ}

Автор выражает свою глубочайшую признательность главному специилисту ФГБУ «27 Научный центр» Министерства обороны Российской Федерации, кандидату биологических наук, старшему научному сотруднику М.В. Супотницкому и старшему научному сотруднику этого же Центра, доктору технических наук, кандидату медицинских наук, Заслуженному химику Российской Федерачии А.И. Банникову за чрезвычайно полезные советы и ценные замечания, высказанные в ходе обсуждения настоящей статьи.

\section{Вклад автора/ Autor Contribution}

Идея и концепция статьи, поиск и анализ литературы, написание статьи цифровая обработка изображений / Idea and concept of an article, search and analysis of literature, writing an article, digital image processing.

\section{Информация о конфликте интересов}

Автор заявляет, что исследования проводились при отсутствии любых коммерческих или финансовых отношений, которые могли бы быть истолкованы как потенциальный конфликт интересов.

Сведения о рецензировании

Статья прошла открытое рецензирование двумя рецензентами, специалистами в данной области. Рецензии находятся в редакции журнала и в РИНЦе. 
Список источников / References

1. Супотницкий М.В., Петров С.В., Ковтун В.А. Влияние химического оружия на тактику и оперативное искусство Первой мировой войны (исторический очерк) // Вестник войск РХБ защиты. 2017. T. 1; № 1. C. 53-68; № 2. С. 39-63; № 3. С. 51-78.

Supotnitskiy M.V., Petrov S.V., Kovtun V.A. The Influence of Chemical Weapons on Tactics and Operational Art in World War 1 (Essays in the History of Chemical Weapons), Part 3 // Journal of NBC Protection Corps. 2017. V. 1; № 1. P. 53-68; № 2. P. 39-63; № 3. P. 51-78 (in Russian).

2. Супотницкий М.В., Петров С.В., Ковтун В.А. Химическое оружие в Первой Мировой войне. М.: Русская панорама, 2020. 446 c.

Supotnitskiy M.V., Petrov S.V., Kovtun V.A. Chemical Weapons in World War I. M.: Russian Panorama, 2020. 446 p. (in Russian).

3. Bretislav Friedrich. From Berlin-Dahlem to the Fronts of World War I: The Role of Fritz Haber and His Kaiser Wilhelm Institute in German Chemical Warfare // One Hundred Years of Chemical Warfare: Research, Deployment, Consequences (pp.25-44) https://doi.org/10.1007/978-3-319-51664-6_3

4. Henning E., Kazemi M. Dahlem - Domain of Science. A walking tour of the Berlin institutes of the Kaiser Wilhelm / Max Planck Society in the "German Oxford». 4th ed., expanded and updated. Berlin. 2009. P. 97.

5. Версальский мирный договор / Полный перевод с французского подлинника под ред. Ключникова Ю.В., Сабанина А. М.: Литиздат НКИД, 1925. С. 67.

Treaty of peace with Germany (treaty of Versailles). Transl. from French orig. Moscow, 1925. 197 p. (in Russian).

6. Войска радиационной, химической и биологической защиты. 100 лет. М., 2018.

Troops of radiation, chemical and biological protection. 100 years. M., 2018.

7. Шило Н.И. Первые попытки запрещения химического оружия // Вестник войск РХБ защиты. 2018. T. 2. № 1. C. $48-69$.

Shilo N.I. First Attempts to Ban Chemical Weapons // Journal of NBC Protection Corps. 2018. V. 2. № 1. P. 48-69 (in Russian).

8. The Problem of Chemical and Biological Warfare. Vol. I. The Rise of CB Weapons. SIPRI, 1971.

9. Mills, A.K. Investigations of Chemical Warfare Installations in the Munsterlager area, including Raubkammer. CIOS File No. XXXI-86, ed. SHAEF Combined Intelligence Objectives Sub-Committee-G-2 Division, London. 1945.

10. Schmaltz F. Neurosciences and Research on Chemical Weapons of Mass Destruction in Nazi Germany // J. History Neurosci.: Basic and Clin. Perspectives. 2006. V. 15. № 3. P. 186-209. http://doi. org/10.1080/09647040600658229

11. Bunnett J.F., Mikolajczyk M. Arsenic and Old Mustard: Chemical Problems in the Destruction of Old Arsenical and «Mustard» Munitions. NATO ASI Series. Disarmament Technologies. V. 19. 1998.
12. Baader G., Lederer S.E., Low M., et al. Pathways to Human Experimentation, 1933-1945: Germany, Japan, and the United States. Osiris. 2005; 20:205-31. https://doi.org/10.1086/649419

13. Brown M. Military Chemical Warfare Agent Human Subjects Testing: Part 1 - History of Six-Decades of Military Experiments with Chemical Warfare Agents // Military Medicine. 2009. V. 174. № 10. P.1041.

14. National Academy of Sciences, Institute of Medicine: Committee to Survey the Health Effects of Mustard Gas and Lewisite: Veterans at Risk: Health Effects of Mustard Gas and Lewisite. Washington, DC, National Academy Press, 1993.

15. Нельга И.А., Медвецкий И.В., Злобин А.В. и др. Химическое оружие: история исследования фосфорорганических отравляющих веществ за рубежом // Вестник войск РХБ защиты. 2019. Т. 3. № 2. C. 175-193.

Nelga I.A., Medvetsky I.V., Zlobin A.V., Tretyakov S.V., Sherstyuk A.V., Kostyuchenko I.V. Chemical Weapons: History of the Study of Organophosphorus Toxic Agents Abroad // Journal of NBC Protection Corps. 2019. V. 3. № 2. P. 175-193 (in Russian).

16. Reitzenstein J. Himmlers Forscher. Wehrwissenschaft und Medizinverbrechen im «Ahnenerbe» des SS. Paderborn: Ferdinand Schöning Verlag, 2014.

17. Рецензия на: Reitzenstein J. Himmlers Forscher. Wehrwissenschaft und Medizinverbrechen im "Ahnenerbe» des SS. Paderborn; Ferdinand Schöning Verlag, 2014. cM. URL: https://www.recensio.net/ rezensionen/zeitschriften/recensio-moskau/2018-9/ ReviewMonograph154519422, https://perspectivia. net/receive/pnet_mods_00000890? (дата обращения: 13.06.2021).

18. Toledano R. Anatomy in the Third Reich - The Anatomical Institute of the Reichsuniversität Strassburg and the deliveries of dead bodies // Ann. Anatomy Anatomischer Anzeiger. 2016. V. 205. P. 128-144. http:// dx.doi.org/10.1016/j.aanat.2016.03.006

19. Lang H.-J. August Hirt and «extraordinary opportunities for cadaver delivery» to anatomical institutes in National Socialism: A murderous change in paradigm // Ann. Anatomy - Anatomischer Anzeiger. 2013. V. 195. № 5. P. 373-380. http://dx.doi.org/10.1016/j. aanat.2013.03.013

20. Schmaltz F. Chemical weapons research in National Socialism: The collaboration of the Kaiser Wilhelm institutes with the military and industry // In: The Kaiser Wilhelm Society under National Socialism / Ed. Heim S., Sachse C., Walker M. Cambridge: Cambridge University Press, 2009. P. 312-338.

21. Ash M.G. Die Kaiser-Wilhelm Gesellschaft im Nationalsozialismus. Published online: 20 April 2010. http://doi.org/10.1007/s00048-009-0011-8

22. F. Lo'pez-Mun oz. The pharmaceutical industry and the German National Socialist Regime: 
I.G. Farben and pharmacological Research. // J. Clin. Pharm. Therapeutics. 2009. V. 34. P. 67-77.

23. Stephen L. McFarland. Preparing for What Never Came: Chemical and Biological Warfare in World War II // Defense Analysis. V. 2. No. 2. 1986. P. 108.

24. Preuss J. The Reconstruction of Production and Storage Sites for Chemical Warfare Agents and Weapons from Both World Wars in the Context of Assessing Former Munitions Sites / Eds. Friedrich B. et al. One Hundred Years of Chemical Warfare: Research, Deployment, Consequences. 2017. P. 291.

25. Пака В.Т. Затопленное химическое оружие: состояние проблемы // Рос. хим. ж. (Ж. Рос. хим. обва им. Д.И. Менделеева). 2004. Т. XLVIII. № 2. С. 106.

Paka V.T. Dumped chemical weapons: the state of the problem // Ross. Chim. Zh. (J. of the Russian Chemical Society named after D.I.Mendeleev). 2004. T. XLVIII. № 2. P. 106 (in Russian).

26. Old Chemical Weapons Reference Guide. May 1998. Section 4-3.

27. U.S. Army Chemical Materiel Destruction Agency. Old Chemical Weapons: Munitions Specification Report. September 1994.

28. Entsorgung von kampfmittelbelasteten Böden am Beispiel der GEKA.

29. Weindling P. The Origins of Informed Consent: The International Scientific Commission on Medical War Crimes, and the Nuremberg Code // Bull. History Med. 2001. V. 75. № 1. P. 37-71.

30. Sass H.-M. Reichsrundschrefben 1931: PreNuremberg German Regulations Concerning New Therapy and Human Experimentation // J. Med. Philosophy. 1983. V. 99. P. 111.

31. Schmaltz F. Chemical Weapons Research on Soldiers and Concentration Camp Inmates in Nazi Germany // In: One Hundred Years of Chemical Warfare: Research, Deployment, Consequences / Eds. Friedrich B. et al. http://doi.org/10.1007/978-3-319-51664-6_13

32. Аристов С.В. Повседневная жизнь нацистских концентрационных лагерей. М.: Молодая гвардия, 2017.

Aristov S.V. Daily life of Nazi concentration camps. Moscow: Young Guard, 2017 (in Russian).

33. Schmaltz F. Otto Bickenbach's Human Experiments with Chemical Warfare Agents and the Concentration Camp Natzweiler // In: Man, Medicine, and the State: the Human Body as an Object of Government Sponsored Medical Research in the 20th Century / Ed. Eckart W.U. Stuttgart: Steiner, 2006. P. 139-156.

34. Schmaltz F. Kampfstoff-Forschung im Nationalsozialismus. Zur Kooperation von KaiserWilhelm-Instituten, Militär und Industrie. Göttingen: Wallstein Verlag, 2005.

35. Daan de Leeuw. In the Name of Humanity. Nazi Doctors and Human Experiments in German Concentration Camps, 1939-1945. University of Amsterdam, Department of History Master's Thesis in History. 2013.

36. Глотова С.В. Преступления против человеч- ности: генезис и современное понимание концепции // Журнал зарубежного законодательства и сравнительного правоведения. № 3. 2016. С. 101-108.

Glotova S.V. Crimes against humanity: genesis and modern understanding of the concept // Journal of Foreign Legislation and Comparative Law. № 3. 2016. P. 101-108 (in Russian).

37. Барсегов Ю.А. Декларация 1915 года - этап формирования международной ответственности за геноцид // Турецкая доктрина международного права на службе политики геноцида (о концепции члена «Комиссии примирения» Гюндюз Актана). М., 2002. URL: http://www.armenianhouse.org/barsegov/ genocide-ru/doctrine/doctrine.html\#6

Barsegov Yu.A. Declaration of 1915 - the stage of formation of international responsibility for genocide // Turkish doctrine of international law in the service of the policy of genocide (on the concept of a member of the "Reconciliation Commission» Gündüz Aktan) M., 2002. URL: http://www.armenianhouse.org/barsegov/ genocide-ru/doctrine/doctrine.html\#6 (in Russian).

38. Валеев Р.М. Кодификация преступлений против человечности (к 70-летию Нюрнбергского процесса) // Юридическая наука. 2015. № 3. С. 69-74.

Valeev R.M. Codification of Crimes Against Humanity (to the 70th Anniversary of the Nuremberg Trials) // Legal Science. 2015. № 3. P. 69-74 (in Russian).

39. Нюрнбергский процесс: Сборник материалов. В 8-ми т. Т. 5. М.: Юрид. лит., 1991. 672 с.

The Nuremberg Trials: Collection of Materials. In 8 volumes.V. 5. M.: Jurid. Lit., 1991.672 p (in Russian).

40. СС в действии. Документы о преступлениях

СС. Перевод с немецкого. М.: СВЕТОТОН, 2000. 624 с.

SS in Action. Documents About SS Crimes. Translated from German. Moscow: SVETOTON, 2000. 624 p. (in Russian).

41. Enactments and Approved Papers of the Control Council and Coordinating Committee. Allied Control Authority. Germany. 1945. Volume I. Legal Division. Office of Military Government for Germany (US). P. 306-307.

42. Trials of war criminals before the Nuernberg military tribunals under Control Council Law No. 10. Volume I. Nuernberg. October 1946-April 1947. (The Medical Case) Washington, D.C.: U.S. Government Printing Office, 1949-1953.

43. Weindling P. From Clinic to Concentration Camp. Reassessing Nazi Medical and Racial Research, 1933-1945. 2017.

44. Benedek T.G. Case Neisser: Experimental Design, the Beginnings of Immunology, and Informed Consent // Perspectives in Biology and Medicine. V. 57. № 2. 2014. P. 249-267.

45. Vollmann J., Winau R. Informed consent in human experimentation before the Nuremberg code. // British Med. J. 1996. V. 313. P. 1445-1447.

46. Vollmann J., Winau R. The Prussian Regulation of 1900: Early Ethical Standards for Human Experimentation in Germany // Ethics and Human 
Research. 1996.V. 18. № 4. P. 9-11.

47. Силуянова И.В. «Нюрнбергский кодекс» и его значение для современной науки // Медицинская этика. 2014. Т. 2. № 1. С. 85-88.

Siluyanova I.V. «Nuremberg Code» and its significance for modern science // Medical Ethics. 2014. V. 2. № 1. P. 85-88 (in Russian).

48. Чучалин А.Г. Добровольное информированное согласие // Пульмонология. 2021. Т. 31. № 1. C. $116-120$.

Chuchalin A.G. Voluntary informed consent // Pulmonology. 2021. V. 31. № 1. P. 116-120 (in Russian).

49. Петрова Т.Н. Античеловечная медицина: запреты Нюрнберга // В сб.: Итоги Нюрнбергского процесса и вызовы современности. Материалы Международной научно-практической конференции / Под общ. ред. Бастрыкина А.И. 2016. С. 157-162.

Petrova T.N. Unhuman medicine: prohibitions of Nuremberg // In: Results of the Nuremberg trial and modern challenges. Materials of the International Scientific and Practical Conference / Ed. A.I. Bastrykin.
2016. P. 157-162 (in Russian).

50. Трубецкова Е.Г. «Записки врача» В. Вересаева в контексте этических проблем современной медицины // Изв. Сарат. ун-та. Нов. сер. Сер. Филология. Журналистика. 2020. Т. 20. № 2. С. 207-211. https://doi.org/10.18500/1817-7115-2020-20-2-207-211

Trubetskova E.G. Notes of a Doctor by V. Veresaev in the Context of Ethical Problems of Contemporary Medicine // Izv. Saratov Univ. (N.S.), Ser. Philology. Journalism. 2020. V. 20. № 2. P. 207-211 (in Russian).

51. Хельсинкская Декларация Всемирной Ассамблеи Врачей. Рекомендации для врачей, осуществляющихбиомедицинскиеисследования//Радиация и риск (Бюллетень Национального радиационноэпидемиологического регистра). 1997. № 10. C. $16-18$.

Helsinki Declaration of the World Assembly of Physicians. Recommendations for Physicians Carrying Out Biomedical Research // Radiation and Risk (Bulletin of the National Radiation Epidemiological Register). 1997. №. 10. P. 16-18 (in Russian).

Об авторе

Федеральное государственное бюджетное учреждение «27 Научный центр» Министерства обороны Российской Федерации, 105005, Российская Федерация, Москва, Бригадирский пер., д. 13.

Шило Наталья Игоревна. Научный сотрудник отдела.

\title{
Development and Human Testing of Chemical Warfare Agents and Means of Treatment of Lesions in Germany in 1933-1945
}

\author{
N.I. Shilo \\ Federal State Budgetary Establishment "27 Scientific Centre» of the Ministry of Defence \\ of the Russian Federation, Brigadirskii Lane 13, Moscow 105005, Russian Federation
}

Received 15 May 2021. Accepted for publication 20 June 2021

Despite serious attention to the issues of war crimes and crimes against humanity, committed on an unprecedented scale in concentration camps in Nazi Germany, the problem of medical experiments on prisoners appears to be one of the least-studied in modern Russian historiography. Moreover, no special attention was paid to testing chemical weapons on humans. The aim of this work is to review the history of the development and testing of chemical warfare agents (CWA) in Germany in 1933-1945. During the First World War, Germany was one of the leading countries in the sphere of military chemistry in the world. After the Versailles treaty this potential was largely lost as a result of the restrictions. After the National Socialist German Workers' Party (NSDAP) came to power, Germany not only restored, but also increased its military power and achieved a qualitative superiority over its opponents in the field of chemical weapons. The tests of CWA, as well as the study of the effectiveness of the means and protocols for the treatment of the lesions caused by CWA, were carried out both by the military structures of the Wehrmacht and the SS, and by civilian research and academic institutions. Experiments on prisoners were carried out in the concentration camps of Dachau, Ravensbrück, Auschwitz-Birkenau, Buchenwald, Sachsenhausen, Natzweiler-Struthof, Neuengamme, etc. Basically, the damaging effects of sulfur mustard and phosgene was investigated. In Auschwitz-Birkenau «a study of the action of 
various chemical preparations was carried out on the orders of German firms». After the war several SS doctors, who performed involuntary experiments on humans, were convicted by military tribunals for war crimes and crimes against humanity. Seven doctors were sentenced to death and executed on June 2, 1948, at the prison for war criminals in Landsberg, Bavaria. As a result of the Nuremberg trials, the Nuremberg Code was drawn up. It was the first international document that introduced ethical standards for scientists engaged in experiments on humans. It consisted of 10 principles, including the necessity of voluntary informed consent of the patient for the participation in medical experiments after providing him with full information about the nature, duration and purpose of the experiment; on the methods of its implementation; about all the perceived inconveniences and dangers associated with the experiment, and, finally, the possible consequences for the physical or mental health of the subject, which may arise as a result of his participation in the experiment.

Keywords: chemical warfare agents; war crimes; Second World War; Germany; testing; concentration camp; Nuremberg trial; crimes against humanity.

For citation: Shilo N.I. Development and Human Testing of Chemical Warfare Agents and Means of Treatment of Lesions in Germany in 1933-1945 // Journal of NBC Protection Corps. 2021. V. 5. № 2.

P. 173-198. https://doi.org/10.35825/2587-5728-2021-5-2-173-198

Conflict of interest statement

The author declares that the research was conducted in the absence of any commercial or financial relationship that could be construed as a potential conflict of interest.

Peer review information

The article has been peer reviewed by two experts in the respective field. Peer reviews are available from the Editorial Board and from Russian Science Citation Index database.

\section{References}

See P. 195-197.

Author

Federal State Budgetary Establishment «27 Scientific Centre» of the Ministry of Defence of the Russian Federation. Brigadirskii Lane 13, Moscow 105005, Russian Federation.

Natalya Igorevna Shilo. Researcher of the Centre.

Contact information:27nc_1@mil.ru 